\title{
Beach nourishment effects on sand porosity variability
}

\author{
J. Román-Sierra *, J.J. Muñoz-Perez, M. Navarro-Pons \\ Applied Physics Department, Sea Sciences Faculty, University of Cadiz, 11510 Puerto Real, Cadiz, Spain
}

\section{A R T I C L E I N F O}

\section{Article history:}

Received 7 June 2013

Received in revised form 7 October 2013

Accepted 10 October 2013

Available online 14 November 2013

\section{Keywords:}

Porosity

Beach sand

Bulk density

Beach nourishment

Grain size analysis

Beach monitoring

\begin{abstract}
A B S T R A C T
A standard assumption in coastal engineering is that the porosity of natural beach sand (non-cohesive) is $40 \%$. However, is this assumption correct for all beach sand? This paper proposes an accurate and simplified method to assess changes in sand porosity after beach nourishment by means of in-situ density surveys through a nuclear densimeter. This novel application has been applied to different beaches in the southwest of Spain according to the tidal range, grain size and beach morphology in several terms. General results show that sand porosities range from $25.6 \%$ to $43.4 \%$ after beach nourishment works. This research can be considered a support tool in coastal engineering to find shifting sand volumes as a result of sand porosity variability after beach nourishment and later marine influence.
\end{abstract}

(C) 2013 Elsevier B.V. All rights reserved.

\section{Introduction}

Coastal erosion is a natural phenomenon that is a growing problem. Over the last few decades, there has been a gradual change from hard to soft coastal defence techniques. For example, beach nourishment has become the favoured erosion mitigation strategy in many areas of the world (Dean, 2003; Trembanis and Pilkey, 1999). Furthermore, periodic artificial nourishment is widely regarded as an acceptable method of beach and dune protection and restoration (Hanson et al., 2002). Several studies regarding the management and economic evaluation of beach erosion and nourishment around the world have been presented (Gomez-Pina et al., 2007; Hamm et al., 2002; Hanson et al., 2002; Muñoz-Perez et al., 2001a; Trembanis and Pilkey, 1999).

According to Dean (2003), after beach nourishment activities are performed, sand volumetric evolution, particularly the proportion of sand volume that remains within the region where the sand was placed, is of interest. The interstitial system of sandy beaches is lacunar, and its dimensions are defined by the sand granulometry and grain shape. The system can be described by features such as the pore size, density, porosity, permeability and water content (McLachlan and Turner, 1994). The bulk density is an indicator of soil compaction, which is related to its porosity and permeability. An important consideration in sediment motion $\left(S_{l}\right)$ is the porosity index $(\eta)$ :

$S_{l}=I_{l} /\left(\rho_{s}-\rho_{w}\right) \cdot g \cdot(1-\eta)$

* Corresponding author. Tel.: + 34 956016595; fax: + 34956016079.

E-mail addresses: jorge.roman@uca.es (J. Román-Sierra), juanjose.munoz@uca.es (J.J. Muñoz-Perez), marina.navarro@uca.es (M. Navarro-Pons). where $\rho_{\mathrm{s}}$ and $\rho_{w}$ are the soil and sea water densities, respectively, $g$ is the acceleration due to gravity, and $\mathrm{I}_{1}$ is the underwater weight of material moved alongshore per second (Kamphuis et al., 1986).

The porosity is a primary determinant of the density and permeability of sediments; therefore, the porosity is a vital input for basin modelling (Chuhan et al., 2002). According to Poizot et al. (2013), the permeability of a sand bed may also be correlated with the sand grains' size (mean, sorting and skewness) and sphericity in addition to the bed porosity.

The porosity of dune and beach sand deposits was studied by Fraser (1935) and Pryor (1973), and the Holocene barrier island sand deposits were studied by Beard and Weyl (1973). Numerous studies of geological and geotechnical engineering applications to measure the maximum and minimum porosities for different grain size distributions and/or sorting coefficients have been conducted (Bloom et al., 2010; Curry et al., 2004; Gaither, 1953; King, 1899). However, none of these authors studied porosity for beach-monitoring purposes. According to the USACE (2002), good porosity data are often not available. The standard assumption in longshore transport computations is that the porosity of natural beds (non-cohesive) is $40 \%$ and the grain content is 60\% (USACE, 2002), but the values for real sand bands are likely to vary significantly from these values (Galvin, 1979).

According to Dean (2003), after a beach nourishment project, some sand volume is lost because waves cause the sand to spread along the shoreline and move offshore, smoothing the shore profile. The primary purpose of this study is to demonstrate that much of the volume loss after beach nourishment procedure can be due to porosity decrease. Our primary hypothesis is that any type of beach nourishment activity results in a significant increase in sand porosity, largely due to the massive and disorganised dumping of a mixture of sediment and water (in this case 20 and $80 \%$, respectively) on the backshore and 
foreshore by a trailing suction hopper dredge. The porosity subsequently decreases until it reaches its native value because of waves and tides cause spatial re-accommodation of the grains. An accurate and novel application of in-situ measurements of the density (and thus porosity) of beach sand using a high-quality nuclear densimeter gauge is described herein.

\section{Study area}

The coastline that is studied is located in the southwest of Spain near the Strait of Gibraltar (Fig. 1) and faces the Atlantic Ocean (Victoria and Camposoto beaches) and the Mediterranean Sea (Atunara beach). Both the Victoria and Camposoto beaches, the former located in the city of Cadiz, are dissipative beaches (Muñoz-Pérez and Medina, 2000; Poizot et al., 2013) composed of medium and fine moderately sorted sands. However, whereas Victoria has a seaside promenade, Camposoto is a natural beach with a backshore dune ecosystem. In contrast, Atunara beach, located just north-east of Gibraltar, is reflective (Masselink and Short, 1993), with a promenade and short transverse breakwaters, and is composed of coarse poorly sorted sand. Most beaches on the Gulf of Cadiz are composed of sands that are 90-95\% quartz and 5-10\% bioclastic material (Muñoz-Perez and Medina, 2010). In the case of the Victoria and Camposoto beaches, borrow sediments have been sourced from the nearby offshore Meca sand bank, a triangular submerged shelf (composed of medium sands) lying at 15 to $20 \mathrm{~m}$ depth $5 \mathrm{~km}$ west of Cape Trafalgar $\left(36^{\circ} 12^{\prime} \mathrm{N} ; 6^{\circ} 05^{\prime} \mathrm{W}\right.$ ) (Román-Sierra et al., 2011). In the case of Atunara beach, the borrow sediments were dredged from an adjacent fishing port. According to the scheme devised by Davies (1964), the study region can be classified as meso- (Atlantic beaches) and microtidal (Mediterranean beaches), with maximum ranges of $3.80-0.20 \mathrm{~m}$ and $1.50-0.00 \mathrm{~m}$ at spring and neap tides, respectively, exhibiting a semidiurnal periodicity.

\section{Materials and methodology}

Monitoring the behaviour of several beaches through topographic levelling enables comparison with previous studies and prediction of future sand requirements to optimise environmental and economic impacts (Muñoz-Perez et al., 2001a). According to the USACE (2002), it is essential to evaluate the behaviour of the grains and void index at different sand beaches, especially before and after beach nourishment. An accurate sand volume can thus be useful for beach nourishment projects. Moreover, knowledge of the sand's density, sand's porosity, sand's grain size, wave height and topography is crucial for achieving these objectives because the wave and tidal climate can change the sorting, grain size and porosity within a sediment bed (Kakinoki et al., 2011).

Other authors have developed different methodologies for determining sand density and porosity. Pryor (1973) used volumetric methods, whereas Lundegard (1992) quantitatively estimated the amount of porosity loss through compaction and cementation. Atkins and McBride (1992), Curry et al. (2004) and Dickinson and Ward (1994) point-counted the upper surface of thin sections of epoxy- or superglue-impregnated samples in reflected light. Among the various methods that have been applied by different researchers (Beard and Weyl, 1973; Roberts et al., 1998), it is worth mentioning the use of diver cores with in-situ conductivity probes and X-ray computed tomography (CT) scanning techniques (Bloom et al., 2010; Briggs et al., 2010). However, Dickinson and Ward (1994) have noted the difficulty of obtaining in-situ sand samples in which porosities can be measured without disturbing the loosely packed grains. In contrast with other techniques, sediment disturbance does not occur during in-situ nuclear densimeter measurements. This technique is also much less laborious, very accurate and non-destructive (Roberts et al., 1998). These properties are very important because grain crushing can result in tighter grain packing and a reduction of the primary porosity (Chuhan et al., 2002), thereby yielding an incorrect measurement.

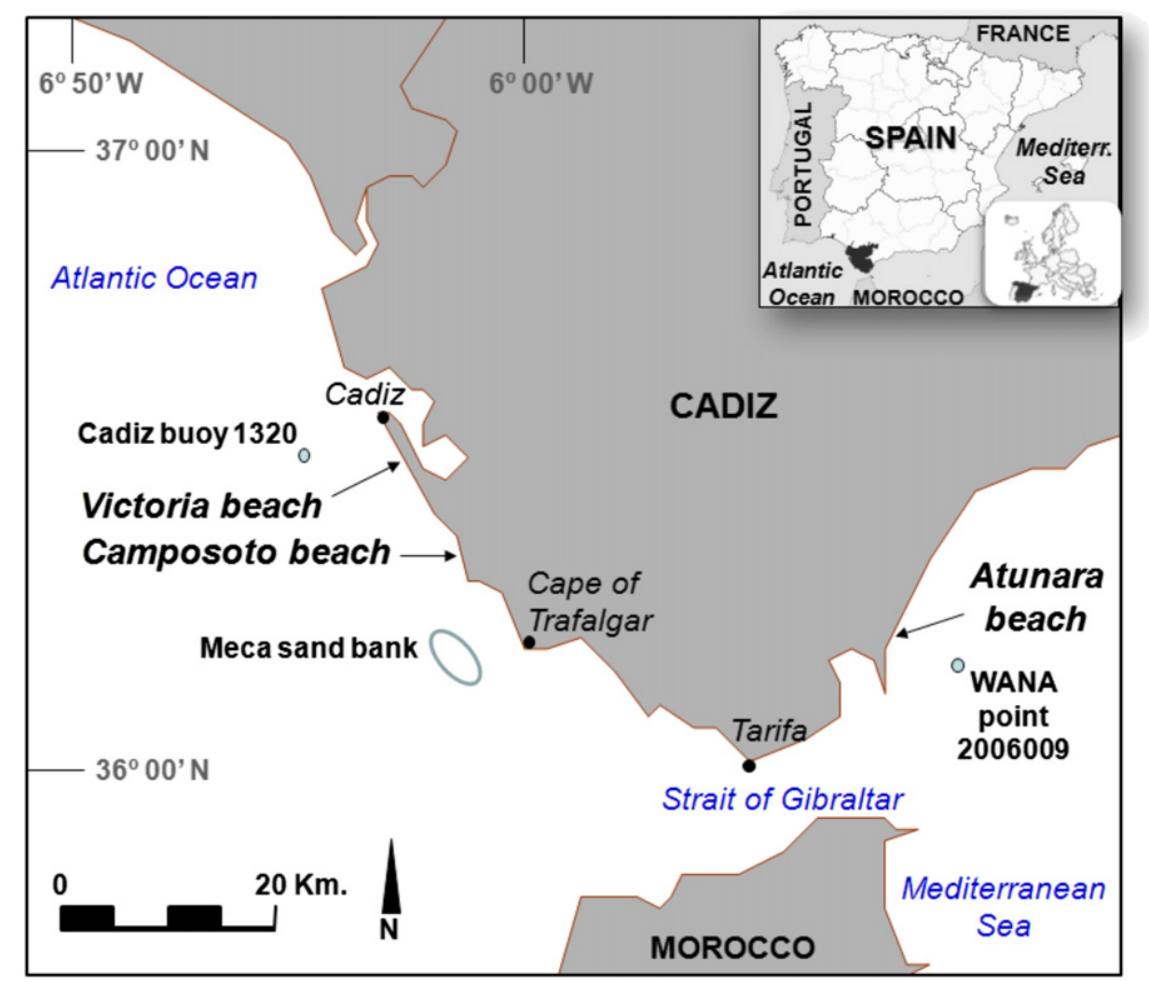

Fig. 1. Locations of the three studied beaches (Victoria, Camposoto and Atunara) and the Meca sand bank (the source of borrow sand for the first two beaches) in southwest Spain. 


\subsection{Method for measuring the in-situ density and water content}

The method used in this work was designed to determine the insitu bulk density and water content of the beach sand layer to a depth of $0.3 \mathrm{~m}$ using a nuclear densimeter gauge (Fig. 2A). According to McLachlan and Turner (1994), the most important processes that occur in this sand layer are water filtration and input of seawater by tides, wave run-up and subtidal wave pumping. In the southwest of Spain, this depth is sufficient for registering changes in the disturbance depth due to tides and waves. Anfuso (2005) established that the values of the disturbance depth are less than $0.22 \mathrm{~m}$, and according to Muñoz-Perez and Medina (2000), the maximum difference of the levelling due to the fortnightly tidal cycle at Victoria Beach was not significantly greater. A methodology to determine the sediment mixing depth for steep and gentle foreshores can be found in Ferreira et al. (2000).

The nuclear densimeter method has been previously used to measure bulk densities of sediments in a laboratory (Roberts et al., 1998), but this method has not been used in beaches. Nuclear density gauges are normally used for quality control and acceptance testing of compacted soil and soil-aggregate mixtures used in civil construction (of roads and earth dams, for example), for which high precision is required. The non-destructive nature of nuclear density gauges enables repetitive measurements at a single test location and the possibility of a statistical analysis of the results.

According to the norm ASTM (2010), a 60-second time interval is used for the counting period. The source extends through the base of the gauge into a predrilled hole and is positioned at a desired depth up to $0.3 \mathrm{~m}$ (12 in.). The detector remains on the surface. The machine determines the density of the material using the attenuation of gamma-ray radiation by counting the number of photons emitted by a radioactive source (caesium-137) and reading them using detector tubes in the gauge base (Fig. 2B). The water mass per unit volume is determined by the thermalisation or slowing of fast neutrons by hydrogen.

To study the density after maximum sediment compaction (within an optimum humidity) for native beach sand and borrowed marine sand, two samples from each beach (collected before and after sand dumping) were taken to the laboratory to undergo the modified Proctor geotechnical compacting test (ASTM, 2012). This test provided the basis for determining the maximum compaction and optimal water content of each sand sample. Using this test, it is possible to determine whether different sands exhibit similar compression behaviour given the same incident energy.

\subsection{Technique for measuring porosity}

Porosity is the volume of the pore space within the unit volume of the sediment bed, whereas the grain content is the sediment fraction of the volume. According to the USACE (2002), porosity can be defined as the ratio of the pore space, or voids, to the entire volume. Density is the mass per unit volume of a material, which is measured in kilograms per cubic meter $\left(\mathrm{kg} / \mathrm{m}^{3}\right)$ in SI units.

Thus, the porosity of a beach sand sample can be easily calculated from the measured bulk density. For a three-component system that consists of sand grains, sea water and atmospheric air, the bulk density $\left(\rho_{b}\right)$ is given by:

$\rho_{b}=\left(\rho_{s} \cdot \alpha\right)+\left(\rho_{w} \cdot \beta\right)+\left(\rho_{a} \cdot \gamma\right)$

where $\rho_{\mathrm{s}}$ is the most representative grain density $\left(2,650 \mathrm{~kg} / \mathrm{m}^{3}\right), \alpha$ is the grain concentration (which is the value to be obtained), $\rho_{w}$ is the sea water density $\left(1,025 \mathrm{~kg} / \mathrm{m}^{3}\right), \beta$ is the water content, $\rho_{a}$ is the air density, and $\gamma$ is the proportion of air in the bulk.

However, compared with the sediment and sea-water densities, the air density $\rho_{a}$ can be considered negligible. Consequently, the third component is approximately zero. Therefore, the grain content can be expressed as follows:

$\alpha=\left[\rho_{b}-\left(\rho_{w} \cdot \beta\right)\right] / \rho_{s}$

Using (3), the sediment porosity can be calculated once the dry bulk density $\left(\mathrm{kg} / \mathrm{m}^{3}\right)$ in-situ registered value is measured. The total volume

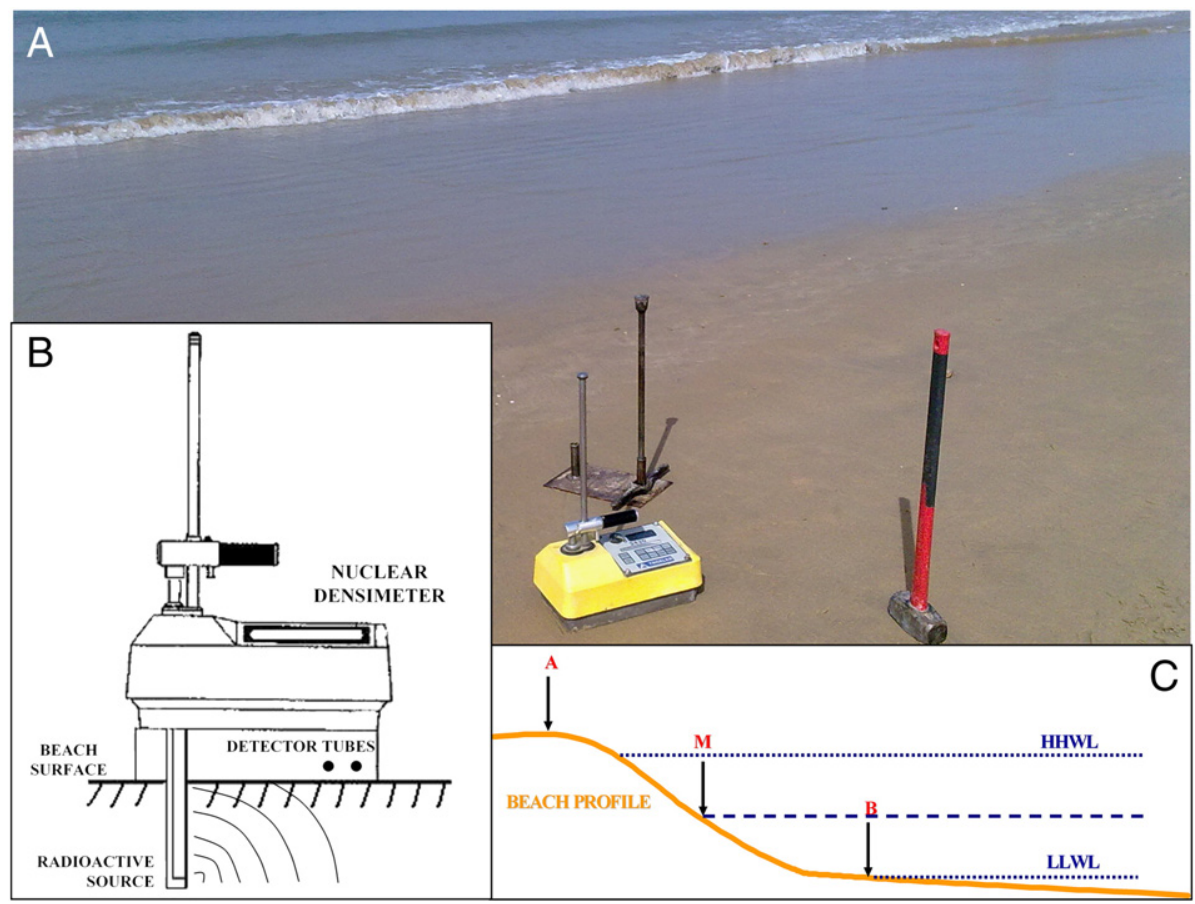

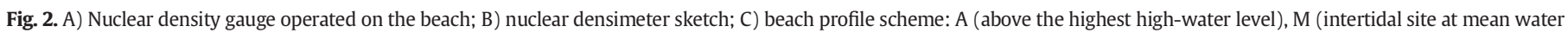
level) and B (close to the lowest low-water level). 
Table 1

Maximum density related to optimal humidity after a modified Proctor compacting test for native beach sand (i.e. before nourishment) and borrow sand dredged from the seabed (after sand dumping).

\begin{tabular}{|c|c|c|c|c|c|c|}
\hline & \multicolumn{2}{|c|}{ Native beach sand } & \multicolumn{2}{|c|}{ Borrowed marine sand } & \multicolumn{2}{|c|}{ Relative differences } \\
\hline & $\begin{array}{l}\text { Density } \\
(\mathrm{kg} / \mathrm{m} 3)\end{array}$ & $\begin{array}{l}\text { Humidity } \\
(\%)\end{array}$ & $\begin{array}{l}\text { Density } \\
(\mathrm{kg} / \mathrm{m} 3)\end{array}$ & $\begin{array}{l}\text { Humidity } \\
(\%)\end{array}$ & $\begin{array}{l}\text { Density } \\
(\%)\end{array}$ & $\begin{array}{l}\text { Humidity } \\
(\%)\end{array}$ \\
\hline Victoria & 1730 & 12.8 & 1710 & 11.3 & 1.2 & 11.7 \\
\hline Camposoto & 1830 & 13.9 & 1770 & 14.4 & 3.3 & 3.5 \\
\hline Atunara & 2020 & 13.5 & 1850 & 12.8 & 8.4 & 5.2 \\
\hline
\end{tabular}

Table 2

Computational precision results based on beach sand heterogeneity established for a $1 \mathrm{~m}^{2}$ area at site $\mathrm{P} 2 \mathrm{M}$

\begin{tabular}{lll}
\hline & Density $\left(\mathrm{kg} / \mathrm{m}^{3}\right)$ & Porosity (\%) \\
\hline Left top corner & 1644 & 38.0 \\
Right top corner & 1650 & 37.7 \\
Left down corner & 1646 & 37.9 \\
Right down corner & 1640 & 38.1 \\
Center & 1656 & 37.5 \\
Mean & $\mathbf{1 6 4 7}$ & $\mathbf{3 7 . 8}$ \\
Std. Dev. & $\mathbf{6 . 1}$ & $\mathbf{0 . 2}$ \\
Max. Abs. Error & $\mathbf{1 6}$ & $\mathbf{0 . 6}$ \\
Max. Rel. Error (\%) & $\mathbf{0 . 9}$ & $\mathbf{1 . 6}$ \\
\hline
\end{tabular}

is defined as the sum of the porosity $(\eta)$ and the grain content $(\alpha)$. Therefore, we can write:

$\eta=1-\alpha$

Using (3) and (4), we can calculate the proportion of grains in sediment and the porosity. The absolute porosity variability and its relative differences are evaluated in combination with grain size analyses and wave data.

\subsection{Field surveys}

The methodology presented above was applied to three beaches in the southwest of Spain with different characteristics regarding the grain size, tide, wave energy and beach morphology. At Victoria, Camposoto and Atunara beaches, two transversal profiles (P1 and P2) were established along the nourished coastline. To study the entire cross-shore profile, the following three sampling sites were settled (Fig. 2c): dry beach at the supratidal zone (A), the intertidal zone (M), and the low-tide zone (B). Because the nuclear densimeter does not function under seawater, the sites in B were taken near the low tidal level. Furthermore, at Victoria beach, an extra point (Mberm), which was located between points $\mathrm{A}$ and $\mathrm{M}$, was used because of the formation of a large berm after sand dumping. Because of the low tidal range at

Table 3

Analytical precision based on the reproducibility of several analyses of samples obtained at the same point at sites P2A and P2M.

\begin{tabular}{llllll}
\hline & \multicolumn{2}{l}{$\mathrm{P} 2 \mathrm{~A}$} & & $\mathrm{P} 2 \mathrm{M}$ \\
\cline { 2 - 3 } \cline { 5 - 6 } & Density $\left(\mathrm{kg} / \mathrm{m}^{3}\right)$ & Porosity $(\%)$ & & Density $\left(\mathrm{kg} / \mathrm{m}^{3}\right)$ & Porosity (\%) \\
\hline Analysis I & 1708 & 35.5 & & 1653 & 37.6 \\
Analysis II & 1706 & 35.6 & & 1665 & 37.2 \\
Analysis III & 1720 & 35.1 & & 1647 & 37.8 \\
Analysis IV & 1728 & 34.8 & & 1643 & 38.0 \\
Analysis V & 1715 & 35.3 & & 1650 & 37.7 \\
Mean & $\mathbf{1 7 1 5}$ & $\mathbf{3 5 . 3}$ & & $\mathbf{1 6 5 2}$ & $\mathbf{3 7 . 7}$ \\
Std. Dev. & $\mathbf{8 . 9}$ & $\mathbf{0 . 3}$ & $\mathbf{8 . 3}$ & $\mathbf{0 . 3}$ \\
Max. Abs. Error & $\mathbf{2 2}$ & $\mathbf{0 . 8}$ & $\mathbf{2 2}$ & $\mathbf{0 . 8}$ \\
Max. Rel. Error (\%) & $\mathbf{1 . 2}$ & $\mathbf{2 . 1}$ & & $\mathbf{1 . 3}$ & $\mathbf{2 . 2}$ \\
\hline
\end{tabular}

Table 4

Historical sand porosity data from published sources. Adapted from Curry et al. (2004) and updated.

\begin{tabular}{|c|c|c|c|c|}
\hline \multirow[b]{2}{*}{ Authors } & \multirow[b]{2}{*}{ Year } & \multicolumn{3}{|c|}{ Sand porosities (\%) } \\
\hline & & Packed & Natural & Loose \\
\hline King & 1899 & 32 & 36.8 & 40 \\
\hline Ellis and Lee & 1919 & - & $40-46.5$ & - \\
\hline Meinzer & 1923 & - & 48 & - \\
\hline Terzaghi & 1925 & 39 & - & 49 \\
\hline Trask & 1931 & - & - & $45.5-47.4$ \\
\hline Graton and Fraser & 1935 & 26 & $35-40$ & 47.6 \\
\hline Fraser & 1935 & - & $41.6-44.2$ & - \\
\hline Tickell and Hiat & 1938 & $37.6-39.4$ & - & - \\
\hline Kolbuszewski & 1948 & 31.6 & - & 49.7 \\
\hline Gaither & 1953 & $36-37.7$ & - & - \\
\hline Hamilton and Menard & 1956 & - & $38.3-47.7$ & - \\
\hline Ludwick & 1956 & - & - & $39.9-47.9$ \\
\hline Breslau & 1967 & - & $39.1-48.2$ & - \\
\hline Erchul and Nacci & 1972 & 35.8 & - & 42.3 \\
\hline Pryor & 1972 & - & $45.0-50.8$ & - \\
\hline Beard and Weyl & 1973 & $23.4-43.5$ & $40.8-44$ & - \\
\hline Erchul & 1974 & $26-32$ & $39.5-41.0$ & $40-47$ \\
\hline Jackson & 1975 & $37.9-38.5$ & 39 & $46.5-48.0$ \\
\hline Jackson et al. & 1978 & $33-60$ & - & $42-66$ \\
\hline Hamilton and Bachman & 1982 & 35 & $38.6-48.5$ & - \\
\hline Packwood & 1983 & - & 30 & - \\
\hline Arulanandan & 1991 & 32 & - & 44 \\
\hline Briggs & 1994 & - & $36.5-44.0$ & - \\
\hline Dickinson and Ward & 1994 & - & $19.6-45.6$ & - \\
\hline Bennett & 1999 & $39-40$ & - & $42-43$ \\
\hline Bennett et al. & 1999 & 37.5 & $41.6-44.5$ & 42 \\
\hline Evans & 2001 & - & $46.5-51.0$ & - \\
\hline Faas & 2001 & $37.0-42.2$ & - & $45.3-48.9$ \\
\hline Richardson et al. & 2001 & - & $36.0-39.9$ & - \\
\hline Chuhan et al. & 2002 & $24.8-32.5$ & $44.5-48.8$ & - \\
\hline Tang et al. & 2002 & 37.2 & - & 39.9 \\
\hline U.S. Army Corps of Engineers & 2002 & 25 & 40 & 50 \\
\hline Wheatcroft & 2002 & - & 37.8 & - \\
\hline Curry et al. & 2004 & 39.3 & - & 51.2 \\
\hline Van Rijn & 2007 & - & 35 & - \\
\hline Briggs et al. & 2010 & - & 36.6 & - \\
\hline Reed et al. & 2010 & - & $36.7-43.6$ & - \\
\hline Román-Sierra et al. & 2013 & - & $25.6-43.4$ & - \\
\hline Averaged historical porosities & & 35.0 & 40.6 & 45.9 \\
\hline
\end{tabular}

Atunara beach, the tidal effects on the porosity variability were not considered.

Complete monitoring of the density, humidity and topographic levellings was performed at all three beaches over the short, medium and long term (days, weeks and months, respectively). The goal of the monitoring was to study the effect of different phenomena on the internal beach sand porosity. Furthermore, the absolute porosity variability and relative differences (with "+" and "-" symbols for increasing and decreasing porosity, respectively) were calculated for all three beaches.

Sand sampling, analysis of the grain size and collection of master samples were performed according to the recommendations proposed by Medina et al. (1994), Román-Sierra et al. (2013) and USACE (2002). Samples were dry sieved for $10 \mathrm{~min}$ in a Ro-Tap sieve shaker machine operated at $2.6 \mathrm{rpm}$ and $300 \mathrm{taps} / \mathrm{min}$. The individual sieve

Table 5

Median grain size and sorting parameter values for native, borrow and final mixture Master sand samples.

\begin{tabular}{|c|c|c|c|c|c|c|}
\hline & \multicolumn{2}{|c|}{ Native beach sand } & \multicolumn{2}{|c|}{ Borrow marine sand } & \multicolumn{2}{|c|}{ Final mixture } \\
\hline & $\begin{array}{l}\mathrm{D}_{50} \\
(\mathrm{~mm}-\mathrm{phi})\end{array}$ & $\begin{array}{l}\text { Sorting } \\
\text { (phi) }\end{array}$ & $\begin{array}{l}\mathrm{D}_{50} \\
(\mathrm{~mm}-\mathrm{phi})\end{array}$ & $\begin{array}{l}\text { Sorting } \\
\text { (phi) }\end{array}$ & $\begin{array}{l}\mathrm{D}_{50} \\
(\mathrm{~mm}-\mathrm{phi})\end{array}$ & $\begin{array}{l}\text { Sorting } \\
\text { (phi) }\end{array}$ \\
\hline Victoria & $0.24-2.06$ & 0.81 & $0.32-1.64$ & 0.88 & $0.24-2.06$ & 0.92 \\
\hline Camposoto & $0.27-1.89$ & 1.12 & $0.32-1.64$ & 0.88 & $0.29-1.79$ & 1.25 \\
\hline Atunara & $0.59-0.76$ & 1.32 & $0.37-1.43$ & 1.26 & $0.49-1.03$ & 1.31 \\
\hline
\end{tabular}


Table 6

Density, humidity and porosity results for Victoria beach sand and observations.

\begin{tabular}{|c|c|c|c|c|c|}
\hline DATE & ZONE & $\operatorname{DENSITY}\left(\mathrm{Kg} / \mathrm{m}^{3}\right)$ & HUMIDITY (\%) & POROSITY (\%) & OBSERVATIONS \\
\hline \multirow[t]{4}{*}{29 days before $\mathrm{P} 1$ nourishment } & P1 A & 1670 & 2.8 & 37.0 & Original state. \\
\hline & P1Mberm & - & - & - & \\
\hline & P1 M & 1756 & 17.2 & 33.7 & \\
\hline & P1 B & 1759 & 19.2 & 33.6 & \\
\hline \multirow[t]{4}{*}{35 days before $\mathrm{P} 2$ nourishment } & $\mathrm{P} 2 \mathrm{~A}$ & 1617 & 2.0 & 39.0 & \\
\hline & P2 Mberm & - & - & - & \\
\hline & $\mathrm{P} 2 \mathrm{M}$ & 1730 & 18.0 & 34.7 & \\
\hline & P2 B & 1696 & 20.0 & 36.0 & \\
\hline \multirow[t]{4}{*}{ P1 nourishment } & P1 A & 1686 & 6.1 & 36.4 & Profile 1 newly nourished. \\
\hline & P1Mberm & 1605 & 4.4 & 39.4 & \\
\hline & P1 M & 1652 & 24.3 & 37.7 & \\
\hline & P1 B & 1659 & 22.5 & 37.4 & \\
\hline \multirow[t]{4}{*}{6 days before $\mathrm{P} 2$ nourishment } & $\mathrm{P} 2 \mathrm{~A}$ & 1613 & 6.0 & 39.1 & A new point P1Mberm is established. \\
\hline & P2 Mberm & - & - & - & \\
\hline & $\mathrm{P} 2 \mathrm{M}$ & 1703 & 20.6 & 35.7 & \\
\hline & P2 B & 1695 & 21.2 & 36.0 & \\
\hline \multirow[t]{4}{*}{1 day after P1 nourishment } & P1 A & 1613 & 4.6 & 39.1 & After the effect of first tidal cycle on P1. \\
\hline & P1Mberm & 1539 & 4.2 & 41.9 & \\
\hline & P1 M & 1665 & 22.4 & 37.2 & \\
\hline & P1 B & 1660 & 22.8 & 37.4 & \\
\hline \multirow[t]{4}{*}{5 days before $\mathrm{P} 2$ nourishment } & $\mathrm{P} 2 \mathrm{~A}$ & 1658 & 4.4 & 37.4 & Profile 2 still have not been nourished. \\
\hline & P2 Mberm & - & - & - & \\
\hline & $\mathrm{P} 2 \mathrm{M}$ & 1697 & 21.5 & 36.0 & \\
\hline & P2 B & 1673 & 24.1 & 36.9 & \\
\hline \multirow[t]{4}{*}{6 days after P1 nourishment } & P1 A & 1541 & 4.7 & 41.8 & Profile 2 newly nourished. \\
\hline & P1Mberm & 1589 & 3.1 & 40.0 & \\
\hline & P1 M & 1705 & 21.5 & 35.7 & \\
\hline & P1 B & 1660 & 24.5 & 37.4 & \\
\hline \multirow[t]{4}{*}{ P2 nourishment } & $\mathrm{P} 2 \mathrm{~A}$ & 1705 & 4.4 & 35.7 & The new point P2Mberm is established. \\
\hline & P2 Mberm & 1593 & 7.5 & 39.9 & \\
\hline & $\mathrm{P} 2 \mathrm{M}$ & 1601 & 25.3 & 39.6 & \\
\hline & P2 B & 1680 & 21.9 & 36.6 & \\
\hline \multirow[t]{4}{*}{7 days after P1 nourishment } & P1 A & 1534 & 3.4 & 42.1 & After the effect of several tidal cycles on P1. \\
\hline & P1Mberm & 1532 & 4.0 & 42.2 & \\
\hline & P1 M & 1697 & 22.8 & 36.0 & \\
\hline & P1 B & 1665 & 22.9 & 37.2 & \\
\hline \multirow[t]{4}{*}{1 day after P2 nourishment } & $\mathrm{P} 2 \mathrm{~A}$ & 1649 & 3.9 & 37.8 & After the effect of the first tidal cycle on P2. \\
\hline & P2 Mberm & 1494 & 6.8 & 43.6 & \\
\hline & $\mathrm{P} 2 \mathrm{M}$ & 1661 & 22.1 & 37.3 & \\
\hline & P2 B & 1643 & 23.7 & 38.0 & \\
\hline 21 days after $\mathrm{P} 1$ nourishment & P1 A & 1602 & 3.0 & 39.5 & After the effect of the equinocctial tides \\
\hline & P1Mberm & 1672 & 4.5 & 36.9 & (tidal range coeff. $=1.12$ ) on $\mathrm{P} 1$ and $\mathrm{P} 2$. \\
\hline & P1 M & 1656 & 21.6 & 37.5 & \\
\hline & P1 B & 1694 & 22.5 & 36.1 & \\
\hline 15 days after $\mathrm{P} 2$ nourishment & P2 A & 1670 & 2.7 & 37.0 & \\
\hline & P2 Mberm & 1536 & 2.9 & 42.0 & \\
\hline & $\mathrm{P} 2 \mathrm{M}$ & 1678 & 20.5 & 36.7 & \\
\hline & P2 B & 1653 & 22.5 & 37.6 & \\
\hline 52 days after $\mathrm{P} 1$ nourishment & P1 A & 1591 & 2.8 & 40.0 & 1 month after equinoctial tides. \\
\hline & P1Mberm & 1576 & 5.4 & 40.5 & \\
\hline & P1 M & 1663 & 23.1 & 37.2 & \\
\hline & P1 B & 1722 & 14.9 & 35.0 & \\
\hline 46 days after $\mathrm{P} 2$ nourishment & P2 A & 1656 & 2.8 & 37.5 & \\
\hline & P2 Mberm & 1586 & 2.8 & 40.2 & \\
\hline & $\mathrm{P} 2 \mathrm{M}$ & 1652 & 21.8 & 37.7 & \\
\hline & P2 B & 1625 & 21.1 & 38.7 & \\
\hline 241 days after P1 nourishment & P1 A & 1622 & 2.8 & 38.8 & After storms ( $\mathrm{Hs}=4 \mathrm{~m})$. \\
\hline & P1Mberm & - & - & - & \\
\hline & P1 M & 1657 & 22.5 & 37.5 & \\
\hline & P1 B & 1742 & 17.3 & 34.3 & \\
\hline 235 days after $\mathrm{P} 2$ nourishment & P2 A & 1632 & 3.3 & 38.4 & \\
\hline & P2 Mberm & 1609 & 5.5 & 39.3 & \\
\hline & $\mathrm{P} 2 \mathrm{M}$ & 1644 & 20.7 & 38.0 & \\
\hline & P2 B & 1681 & 18.5 & 36.6 & \\
\hline 452 days after P1 nourishment & P1 A & 1640 & 1.9 & 38.1 & After storm $(\mathrm{Hs}=4 \mathrm{~m})$. \\
\hline & P1Mberm & 1549 & 2.3 & 41.5 & \\
\hline & P1 M & 1685 & 20.7 & 36.4 & \\
\hline & P1 B & 1693 & 20.0 & 36.1 & \\
\hline 446 days after P2 nourishment & $\mathrm{P} 2 \mathrm{~A}$ & 1668 & 2.1 & 37.1 & \\
\hline & P2 Mberm & 1650 & 2.2 & 37.7 & \\
\hline & $\mathrm{P} 2 \mathrm{M}$ & 1632 & 22.4 & 38.4 & \\
\hline & P2 B & 1619 & 23.2 & 38.9 & \\
\hline
\end{tabular}


fractions (larger than 2, 1, 0.71, 0.5, 0.35, 0.25, $0.12 \mathrm{~mm}$, and smaller than $0.12 \mathrm{~mm}$ ) were subsequently weighed using a $0.01 \mathrm{~g}$ precision balance. After each analysis, the sieve weight, retained percentage, percentage passing, analysis liability, granulometric curve and histogram with trend line for each sieve were computed according to Román-Sierra et al. (2013). By following the methodology used by Muñoz-Perez et al. (2012) and Navarro et al. (2011), the accurate profile topography was obtained by using DGPS during data processing.

Wave data values were obtained from the deep water Cádiz triaxys buoy $1320(36.50 \mathrm{~N} ; 6.33 \mathrm{~W})$ in the Atlantic Ocean (Muñoz-Perez et al., 2001b) for Victoria and Camposoto beaches (Fig. 1) and from
WANA point 2006009 (36.13 N; $5.15 \mathrm{~W}$ ) in the Mediterranean Sea for Atunara beach (Spanish Port System, 2012).

\subsection{Accuracy and precision of the methodology}

The accuracy of the analysis presented here depends on the beach heterogeneity, whereas the precision of the analysis, which is the reproducibility of the results, depends on the reliability of the surveying device. First, the error associated with sand beach heterogeneity was assessed by comparing the results obtained from five equally spaced registers collected in the same small area $\left(1 \mathrm{x} 1 \mathrm{~m}^{2}\right)$. Second, the errors
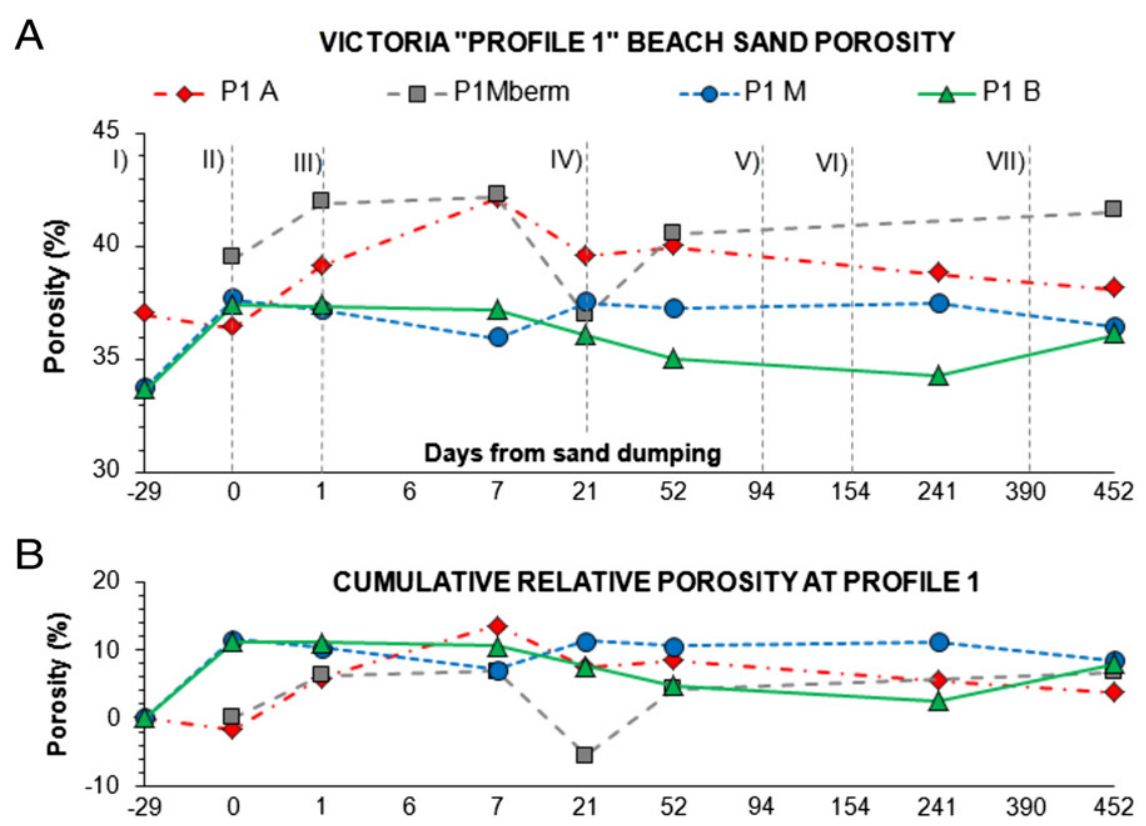

C
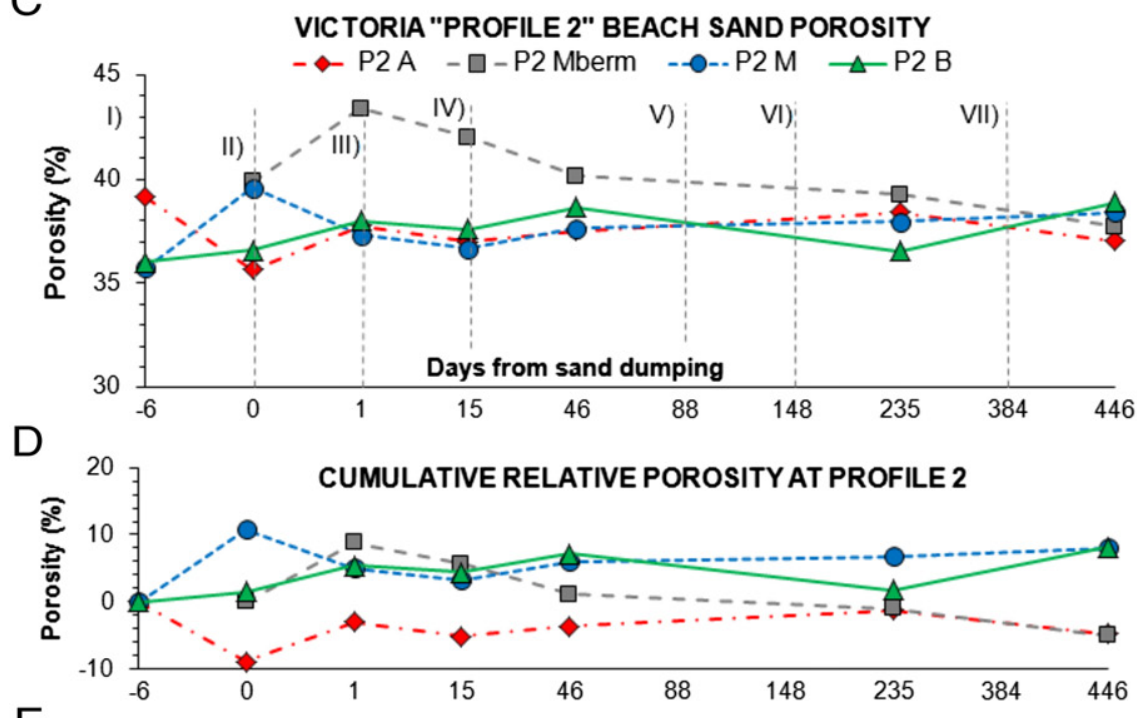

$E$

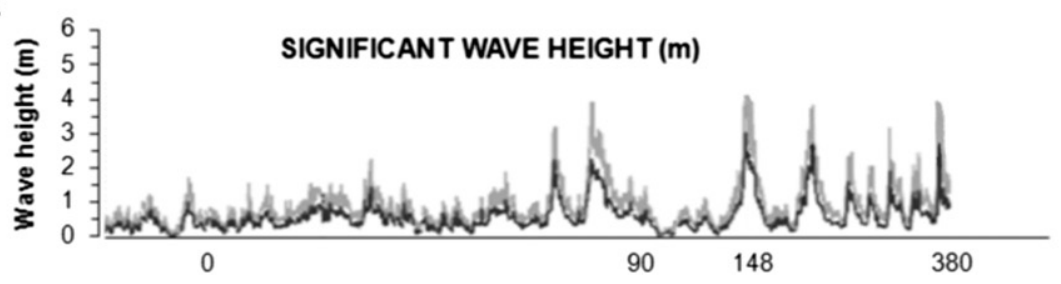

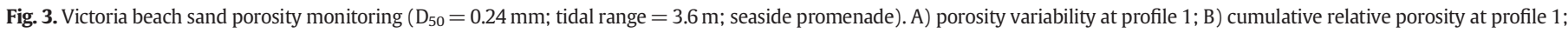

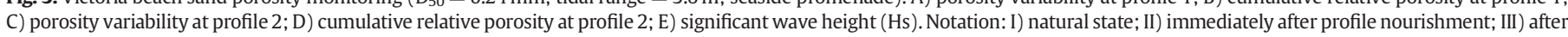
$12 \mathrm{~h}$; IV) after equinoctial tides; V) storm $\mathrm{Hs}=4 \mathrm{~m}$; VI) storm $\mathrm{Hs}=4 \mathrm{~m}$; VII) storm $\mathrm{Hs}=4 \mathrm{~m}$. 
linked to the density gauge were assessed by repeatedly registering the same point several times. Through this procedure, the variability associated with the nuclear densimeter method was determined. This determination was possible because the density gauge does not disturb the sediment bed (Roberts et al., 1998). Tests were also conducted at both supratidal and intertidal sites in order to estimate the influence of humidity. In all cases, the mean, standard deviation, maximum absolute error and maximum relative error of density $\left(\mathrm{kg} / \mathrm{m}^{3}\right)$ and porosity (\%) data were calculated. The maximum absolute and relative errors are expressed as follows:

Max. Abs. Error $\left(\mathrm{kg} / \mathrm{m}^{3}\right)=($ Max. value-Min. value $)$

Max. Rel. Error $(\%)=[1-($ Min. value $/$ Max. value $)] \cdot 100$

\section{Results}

The results obtained from the studied beaches are presented here and are compared with the literature. Previously, the precision of the method related to both sand beach heterogeneity and the nuclear density gauge was also analysed.

\subsection{Modified Proctor test}

To determine the behaviours of native and borrowed sands under the same energetic conditions, the maximum densities and optimal humidities for the three studied beaches are presented in Table 1. In general, the maximum density of native sand was slightly greater than that of borrowed sand, with relative differences of $+1.2,+3.3$ and $+8.4 \%$ at Victoria, Camposoto and Atunara beaches, respectively.

\subsection{Errors}

To estimate the error introduced in the field density analyses, five registers were taken in a small area $\left(1 \mathrm{x} 1 \mathrm{~m}^{2}\right)$. An inter-tidal locality was selected at the Victoria beach profile (P2M). The density and porosity values were determined following the aforementioned methodology. The density and porosity results of the analyses indicated maximum relative errors of 0.9 and $1.6 \%$, respectively (Table 2 ).

To determine the precision (i.e., the reproducibility of the results) of the applied methodology, the same point was analysed five times at the dry beach (P2A) and the intertidal beach (P2M). At both sites, similar density and porosity values were obtained, with maximum relative errors of 1.3 and $2.2 \%$, respectively (Table 3 ), which is of the same order of magnitude as in the heterogeneity case. As a matter of fact, Dickinson and Ward (1994) and Roberts et al. (1998) obtained similar errors, which are related to the accuracy of the method for determining sand porosity.

According to data published by several authors (Table 4) who employed a variety of different methodologies, beach sand porosity values range from 19.6 to $66 \%$ (a variability of $46.4 \%$ ). The average porosities of historically studied natural, loose and packed sands are $35,40.6$ and $45.9 \%$, respectively, with a range of grain sizes (from 0.07 to $2.54 \mathrm{~mm}$ ) and sorting coefficients (from 1.05 to 4.2 ). USACE (2002) states that the porosity ranges from $25 \%$ to $50 \%$ in natural sand $(2-0.063 \mathrm{~mm})$ and does not directly depend on grain size but that it is sensitive to the sediment grain shape, roughness angularity and sorting (Dickinson and Ward, 1994). According to Reis and Gama (2010), Soulsby (1991) and Van Rijn (2007), the porosity of a pure marine sand bed is around 35\%. However, other recent studies (Briggs et al., 2010; Reed et al., 2010; Tang et al., 2002; Wheatcroft, 2002) have recorded a variety of marine sand porosities, obtained via different techniques, ranging from 36.6 to $43.6 \%$ for quartz sands comprised of up to $98 \%$ sand particles (a composition very similar to that of the beaches on the Gulf of Cadiz).

\subsection{Results for Victoria beach}

The native Victoria beach sand master sample was composed of medium sand with a median grain diameter $\left(D_{50}\right)$ of $0.24 \mathrm{~mm}(2.06$ phi), corresponding to a moderately sorted sand (sorting $=0.81 \mathrm{phi}$ ). Although the offshore borrow sand had a $\mathrm{D}_{50}$ of $0.32 \mathrm{~mm}$ (1.64 phi), it was also classified as moderately sorted (sorting $=0.88$ phi). The final master sample (Medina et al., 1994) collected after the completion

Table 7

Density, humidity and porosity results for Camposoto beach sand and observations.

\begin{tabular}{|c|c|c|c|c|c|}
\hline DATE & ZONE & $\begin{array}{l}\text { DENSITY } \\
\left(\mathrm{Kg} / \mathrm{m}^{3}\right)\end{array}$ & $\begin{array}{l}\text { HUMIDITY } \\
(\%)\end{array}$ & $\begin{array}{l}\text { POROSITY } \\
(\%)\end{array}$ & OBSERVATIONS \\
\hline \multirow{3}{*}{$\begin{array}{l}37 \text { days before P1 } \\
\text { nourishment }\end{array}$} & P1 A & 1738 & 2.9 & 34.4 & \multirow[t]{6}{*}{ Natural State. } \\
\hline & P1 M & 1809 & 16.0 & 31.7 & \\
\hline & P1 B & 1714 & 20.8 & 35.3 & \\
\hline \multirow{3}{*}{$\begin{array}{c}5 \text { days before } \mathrm{P} 2 \\
\text { nourishment }\end{array}$} & P2 A & 1846 & 2.9 & 30.3 & \\
\hline & P2 M & 1757 & 18.2 & 33.7 & \\
\hline & P2 B & 1695 & 20.2 & 36.0 & \\
\hline \multirow{2}{*}{$\begin{array}{c}32 \text { days before P1 } \\
\text { nourishment }\end{array}$} & P1 A & 1800 & 1.1 & 32.1 & \multirow{6}{*}{$\begin{array}{l}\text { Profile } 1 \text { newly } \\
\text { nourished. } \\
\text { P1 still have not } \\
\text { been nourished. }\end{array}$} \\
\hline & P1 M & 1868 & 16.0 & 29.5 & \\
\hline \multirow[t]{4}{*}{ P2 nourishment } & P1 B & 1738 & 19.6 & 34.4 & \\
\hline & P2 A & 1585 & 3.9 & 40.2 & \\
\hline & P2 M & 1676 & 18.6 & 36.8 & \\
\hline & P2 B & 1601 & 23.6 & 39.6 & \\
\hline \multirow{3}{*}{$\begin{array}{l}2 \text { days before P1 } \\
\text { nourishment }\end{array}$} & P1 A & - & - & - & \multirow{6}{*}{$\begin{array}{l}\text { P1 was been } \\
\text { nourished at } \\
\text { that moment. }\end{array}$} \\
\hline & P1 M & - & - & - & \\
\hline & P1 B & - & - & - & \\
\hline \multirow{3}{*}{$\begin{array}{l}1 \text { day after P2 } \\
\text { nourishment }\end{array}$} & P2 A & 1613 & 4.3 & 39.1 & \\
\hline & P2 M & 1685 & 17.2 & 36.4 & \\
\hline & P2 B & 1621 & 22.6 & 38.8 & \\
\hline \multirow[t]{3}{*}{ P1 nourishment } & P1 A & 1686 & 5.3 & 36.4 & \multirow{6}{*}{$\begin{array}{l}\text { Profile } 0 \text { newly } \\
\text { nourished. After } \\
\text { the effect of the } \\
\text { first tidal cycles } \\
\text { on P1. }\end{array}$} \\
\hline & P1 M & 1700 & 19.8 & 35.8 & \\
\hline & P1 B & 1702 & 21.6 & 35.8 & \\
\hline \multirow{3}{*}{$\begin{array}{c}3 \text { days after P2 } \\
\text { nourishment }\end{array}$} & P2 A & 1642 & 3.8 & 38.0 & \\
\hline & P2 M & 1652 & 12.8 & 37.7 & \\
\hline & P2 B & 1676 & 21.8 & 36.8 & \\
\hline \multirow{3}{*}{$\begin{array}{l}1 \text { day after P1 } \\
\text { nourishment }\end{array}$} & P1 A & 1632 & 3.3 & 38.4 & \multirow{6}{*}{$\begin{array}{l}\text { After the effect } \\
\text { of the first tidal } \\
\text { cycles on P1. }\end{array}$} \\
\hline & P1 M & 1673 & 21.0 & 36.9 & \\
\hline & P1 B & 1712 & 21.0 & 35.4 & \\
\hline \multirow{3}{*}{$\begin{array}{l}4 \text { days after P2 } \\
\text { nourishment }\end{array}$} & P2 A & 1603 & 4.5 & 39.5 & \\
\hline & P2 M & 1588 & 17.8 & 40.1 & \\
\hline & P2 B & 1669 & 21.5 & 37.0 & \\
\hline \multirow{3}{*}{$\begin{array}{r}25 \text { day after P1 } \\
\text { nourishment }\end{array}$} & P1 A & 1675 & 2.7 & 36.8 & After the effect of \\
\hline & P1 M & 1641 & 18.3 & 38.1 & the equinocctial \\
\hline & P1 B & 1741 & 19.4 & 34.3 & tides (tidal range \\
\hline 28 days after $\mathrm{P} 2$ & P2 A & 1662 & 3.3 & 37.3 & coeff. $=1.12$ ) on \\
\hline nourishment & P2 M & 1628 & 15.6 & 38.6 & $\mathrm{P} 1$ and $\mathrm{P} 2$. \\
\hline & P2 B & 1657 & 20.4 & 37.5 & \\
\hline 64 day afterP1 & P1 A & 1747 & 19.5 & 34.1 & 64 days after \\
\hline nourishment & P1 M & 1703 & 22.2 & 35.7 & nourishing and \\
\hline 67 days after P2 & P1 B & 1672 & 4.2 & 36.9 & 25 days after \\
\hline nourishment & P2 A & 1615 & 4.6 & 39.1 & beach works. \\
\hline & P2 M & 1677 & 11.6 & 36.7 & \\
\hline & P2 B & 1659 & 21.1 & 37.4 & \\
\hline 112 day after P1 & P1 A & 1764 & 13.0 & 33.4 & After short storm \\
\hline nourishment & P1 M & 1688 & 21.2 & 36.3 & $(\mathrm{Hs}=4 \mathrm{~m})$ \\
\hline & P1 B & - & - & - & \\
\hline 115 days after P2 & P2 A & 1712 & 14.9 & 35.4 & \\
\hline nourishment & P2 M & 1708 & 19.4 & 35.5 & \\
\hline & P2 B & - & - & - & \\
\hline 257 day after P1 & P1 A & 1747 & 2.0 & 34.1 & After storms \\
\hline nourishment & P1 M & 1689 & 19.3 & 36.3 & $(\mathrm{Hs}=4 \mathrm{~m})$ \\
\hline & P1 B & 1777 & 14.6 & 32.9 & \\
\hline 260 days after P2 & P2 A & 1697 & 3.0 & 36.0 & \\
\hline nourishment & P2 M & 1767 & 16.7 & 33.3 & \\
\hline & P2 B & 1689 & 16.1 & 36.3 & \\
\hline 467 day after P1 & P1 A & 1742 & 3.5 & 34.3 & After storm \\
\hline nourishment & P1 M & 1643 & 21.0 & 38.0 & $(\mathrm{Hs}=4 \mathrm{~m})$ \\
\hline & P1 B & 1727 & 20.5 & 34.8 & \\
\hline 470 days after P2 & P2 A & 1717 & 3.5 & 35.2 & \\
\hline nourishment & P2 M & 1789 & 12.5 & 32.5 & \\
\hline & P2 B & 1689 & 21.0 & 36.3 & \\
\hline
\end{tabular}


of beach nourishment works exhibited the following values: $\mathrm{D}_{50}=0.24 \mathrm{~mm}$ (2.06 phi) and sorting $=0.92 \mathrm{phi}$ (Table 5$)$. All of the density, humidity and porosity results from Victoria beach can be found in Table 6 .

The porosity of the native Victoria beach sand ranged from 34 to $39 \%$ (Fig. $3 \mathrm{~A}$ and $\mathrm{C}$ ). In the short term, immediately after sand dumping (Volume density $=100 \mathrm{~m}^{3} / \mathrm{m}$ ), the porosity remained practically constant at the dry beach in both profiles but increased drastically at P1M (+11.6\%), P1B (+11.2\%) and P2M (+10.8\%). After the first tidal cycle $(12 \mathrm{~h})$, the porosity increased at the dry beach and at the new points P1Mberm $(+6.3 \%)$ and P2Mberm $(+8.8 \%)$, remained practically constant at the low tidal zones, and decreased by 5.7\% at P2M. One week after sand dumping, the porosity increased at P1A $(+7.6 \%)$, decreased at P1M $(-3.2 \%)$ and did not change at P1Mberm and P1B. Furthermore, the equinoctial tides (i.e., the highest tidal range of the year, with a coefficient (Godin, 1972) of 1.12, which happened 14 days after the nourishment activities) decreased the porosity; the maximum relative difference was $-12.5 \%$ at P1Mberm. In the long term, all porosity values decreased to reach the native values of the sand beach, although the porosity increased again by $5.4 \%$ and $6.4 \%$ at $\mathrm{P} 1 \mathrm{~B}$ and $\mathrm{P} 2 \mathrm{~B}$, respectively, after the last storm ( $\mathrm{Hs}=4 \mathrm{~m})$ happened 400 days after the works (Fig. 3E). The cumulative variability curves (Fig. 3B and D) demonstrate

A

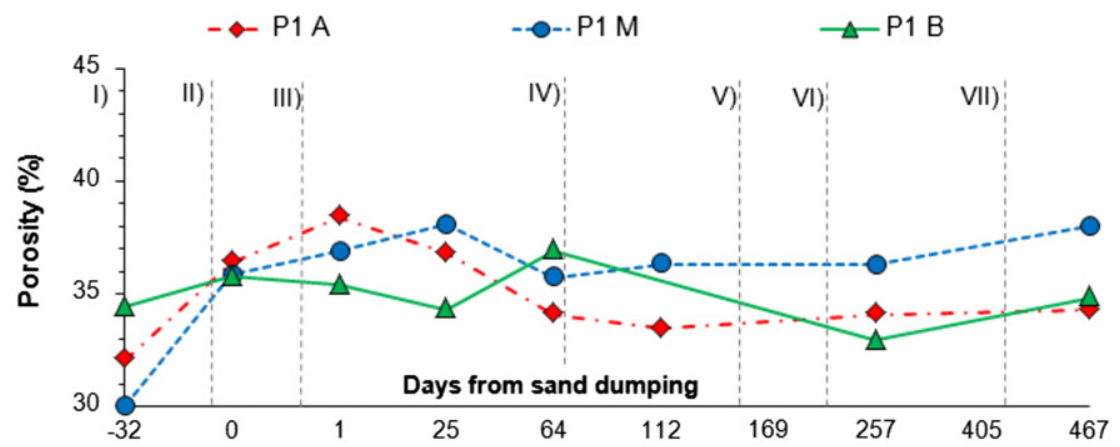

B

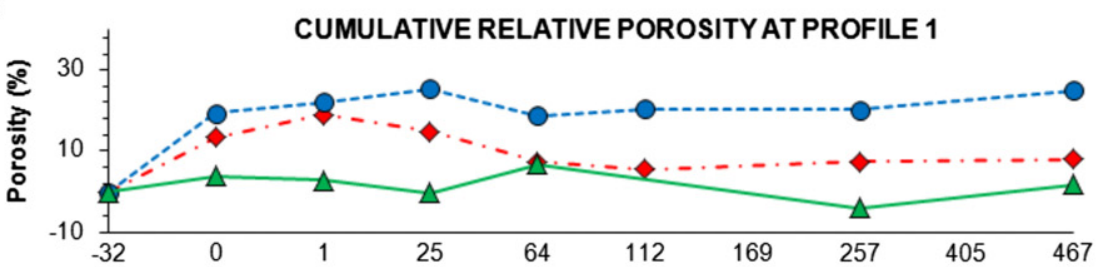

C

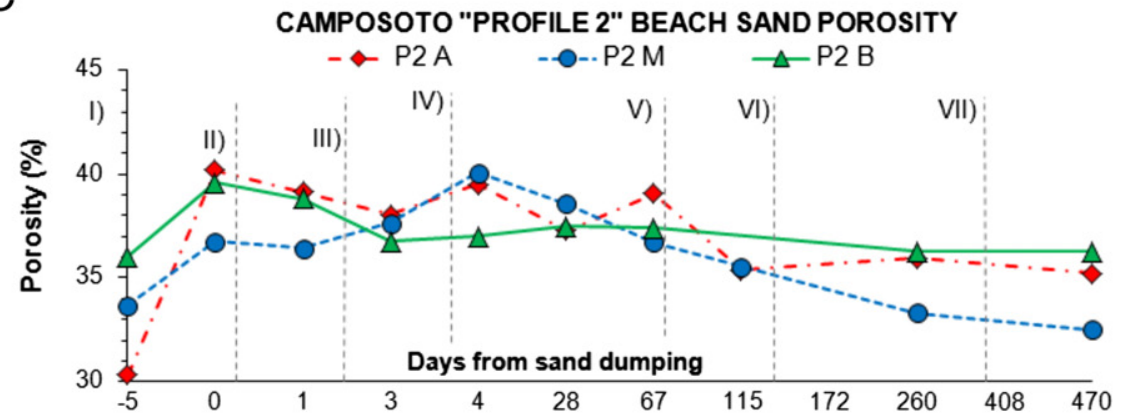

$\mathrm{D}$

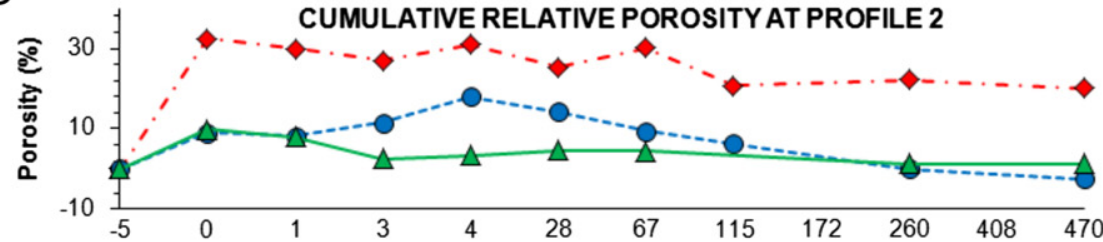

$E$

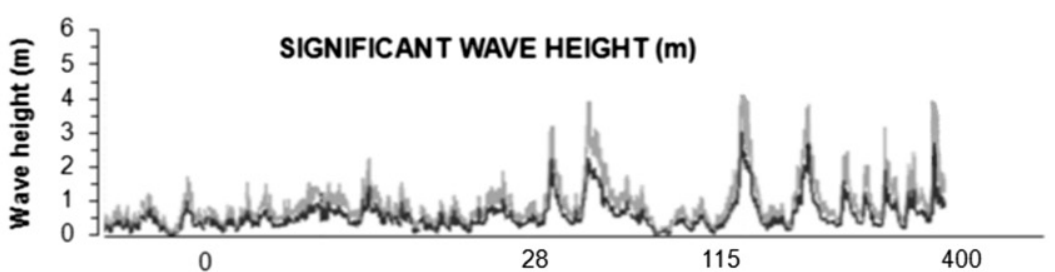

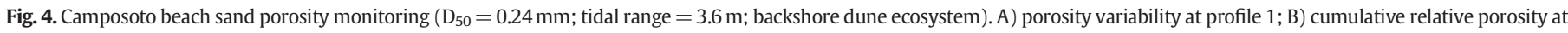

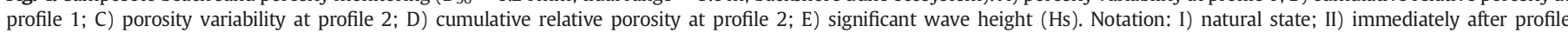
nourishment; III) after $24 \mathrm{~h}$; IV) after equinoctial tides; V) storm Hs $=4 \mathrm{~m}$; VI) storm Hs $=4 \mathrm{~m}$; VII) storm $\mathrm{Hs}=4 \mathrm{~m}$. 
that the porosity typically recovered its native value eight months after beach nourishment. The high variability of the porosity in the short term (after sand dumping) was important, and the porosity ranged from 33\% to $42 \%$ in profile 1 (Fig. 3 A).

\subsection{Results for Camposoto beach}

The native Camposoto beach master sample corresponded to a medium sand, with poorly sorted grains (sorting $=1.12 \mathrm{phi}$ ) of mean size $0.27 \mathrm{~mm}$ ( $1.89 \mathrm{phi}$ ). The borrow sand was the same as that employed for Victoria beach nourishment. At the end of the study period, the sediment exhibited the following values: $D_{50}=0.29 \mathrm{~mm}$ (1.79 phi) and sorting $=1.25$ phi (Table 5 ). Sand density, humidity and porosity results obtained for this beach are presented in Table 7.

The native sand in Camposoto beach had porosity values between $30 \%$ and $40 \%$ (Fig. $4 \mathrm{~A}$ and C). In the short term, after sand dumping (Volume density $=120 \mathrm{~m}^{3} / \mathrm{m}$ ), all these porosity values increased, with maximum relative differences of $+19.3 \%$ and $+32.5 \%$ at $\mathrm{P} 1 \mathrm{M}$ and $\mathrm{P} 2 \mathrm{~A}$, respectively. The maximum porosity variability ranged from $30 \%$ to $40 \%$ in profile 2 (Fig. 4 C). During the first two tidal cycles $(24 \mathrm{~h})$, the porosity continued to increase slightly, with relative differences of less than $+5.6 \%$ but +26.8 and $+18.9 \%$ at P1M and P2M, respectively (after 25 days). The cumulative effect of several tides and the equinoctial tides in the medium term caused a first decrease of $6 \%$ of the porosity at P2A. Despite the storms (Fig. 4E) that occurred in the long term (110 and 170 days after sand dumping, with $\mathrm{Hs}=5$ and $4 \mathrm{~m}$, respectively), the porosity continued to decrease in both profiles. Moreover, P2M decreased at the last stage, with a cumulative relative difference of porosity loss of $-18.9 \%$ regarding the maximum value (Fig. 4C and D). Typically, the porosities reached the native values of the sand beach after eight months. At the end of the study period, the porosity values at P2A and P1A were approximately constant and exhibited values similar to the original range.

\subsection{Results for Atunara beach}

Atunara is a microtidal beach originally composed of coarse $\left(D_{50}=0.59 \mathrm{~mm}, 0.76 \mathrm{phi}\right)$ and poorly sorted sands (sorting $=1.32$ phi). The borrow material used was a poorly sorted (sorting $=1.26$ phi) medium sand, with a value of $D_{50}$ equal to $0.37 \mathrm{~mm}$ (1.43 phi). The final collected master sample was found to be a medium and coarse sand $\left(D_{50}=0.49 \mathrm{~mm}=1.03 \mathrm{phi}\right.$ ) with poor sorting ( $1.31 \mathrm{phi}$ ) (Table 5). Sand density, humidity and porosity results for this beach are presented in Table 8.

The original porosities in Atunara beach were found to be less than those at the Atlantic beaches and ranged from 25.6\% to 35.7\% (Fig. 5A and C). These low porosities, especially at "B" zones, seemed to be produced by poorly sorted sand (Beard and Weyl, 1973; USACE, 2002), where the small grains can fit into the pore spaces of the large grains. Immediately after sand dumping (Volume density $=150 \mathrm{~m}^{3} / \mathrm{m}$ ), the porosity exhibited maximum percentage increases of $16.7 \%, 25.8 \%$ and $36.2 \%$ at the "A", "M" and " $\mathrm{B}$ " zones, respectively. In the short term the maximum porosity variability ranged from $30 \%$ to $40 \%$ in profile 2 (Fig. 5 C). In the medium term, the porosity increased at P2B and reached a value of $41.4 \%$ ( $+47.7 \%$ accumulated from the original values), whereas the porosities decreased by approximately $14 \%$ at P1M and P1B and remained at their native values in the long term. Eight months after the nourishment activities, the porosities decreased by $20.1 \%$ and 33.0\% (at P2M and P2B, respectively) and attained their original values, whereas the dry beach porosity was approximately stable during the entire research period after the nourishment activities (Fig. 5B and D). The porosity values at the $\mathrm{M}$ and $\mathrm{B}$ zones exhibited similar behaviour, although the porosity variability registered at P2 was greater than that at P1.
Table 8

Density, humidity and porosity results for Atunara beach sand and observations.

\begin{tabular}{|c|c|c|c|c|c|}
\hline DATE & ZONE & $\begin{array}{l}\text { DENSITY } \\
(\mathrm{Kg} / \mathrm{m} 3)\end{array}$ & $\begin{array}{l}\text { HUMIDITY } \\
\text { (\%) }\end{array}$ & $\begin{array}{l}\text { POROSITY } \\
(\%)\end{array}$ & OBSERVATIONS \\
\hline \multirow{6}{*}{$\begin{array}{l}57 \text { days before beach } \\
\text { nourishment }\end{array}$} & P1A & 1770 & 4.1 & 33.2 & \multirow[t]{6}{*}{ Natural state. } \\
\hline & P1M & 1800 & 2.4 & 32.1 & \\
\hline & P1B & 1929 & 4.8 & 27.2 & \\
\hline & P2A & 1703 & 4.0 & 35.7 & \\
\hline & P2M & 1737 & 2.6 & 34.5 & \\
\hline & P2B & 1971 & 8.8 & 25.6 & \\
\hline \multirow[t]{6}{*}{ Beach nourishment } & P1A & 1623 & 3.3 & 38.8 & \multirow{6}{*}{$\begin{array}{l}\text { Just after } \\
\text { nourishing } \\
\text { works. }\end{array}$} \\
\hline & P1M & 1581 & 13.1 & 40.3 & \\
\hline & P1B & 1837 & 8.9 & 30.7 & \\
\hline & $\mathrm{P} 2 \mathrm{~A}$ & 1751 & 3.0 & 33.9 & \\
\hline & P2M & 1601 & 3.3 & 39.6 & \\
\hline & P2B & 1725 & 14.7 & 34.9 & \\
\hline \multirow{6}{*}{$\begin{array}{l}41 \text { days after beach } \\
\text { nourishment }\end{array}$} & P1A & 1675 & 2.6 & 36.8 & \multirow{6}{*}{$\begin{array}{l}\text { After storm } \\
(\mathrm{Hs}=4 \mathrm{~m}) .\end{array}$} \\
\hline & P1M & 1525 & 3.9 & 42.5 & \\
\hline & P1B & 1553 & 4.5 & 41.4 & \\
\hline & P2A & 1623 & 3.3 & 38.8 & \\
\hline & P2M & 1746 & 3.6 & 34.1 & \\
\hline & P2B & 1825 & 8.0 & 31.1 & \\
\hline \multirow{6}{*}{$\begin{array}{l}252 \text { days after beach } \\
\text { nourishment }\end{array}$} & P1A & 1649 & 3.5 & 37.8 & \multirow{6}{*}{$\begin{array}{l}\text { After storm } \\
(\mathrm{Hs}=3 \mathrm{~m}) \text {. }\end{array}$} \\
\hline & P1M & 1751 & 3.1 & 33.9 & \\
\hline & P1B & 1915 & 6.1 & 27.7 & \\
\hline & $\mathrm{P} 2 \mathrm{~A}$ & 1628 & 3.2 & 38.6 & \\
\hline & P2M & 1670 & 4.6 & 37.0 & \\
\hline & P2B & 1859 & 10.5 & 29.8 & \\
\hline
\end{tabular}

The topographic profiles of the three beaches (at the original state, immediately after sand dumping and 1 year after the beach nourishment) are shown in Fig. 6. In the long term, topographic levelling generally recovered its natural slope one year after the nourishment activities.

\section{Discussion}

The modified Proctor compaction test indicated that the potential compression (i.e., maximum density) of borrowed sand was slightly less than that of native sand. This fact could be an important factor in understanding porosity variability.

The accuracy of this methodology, which is used to study sand beach heterogeneity and the repetitiveness of the use of the nuclear densimeter gauge, has been estimated by different surveying tests. The maximum relative errors in the density and porosity measurements were approximately 1 and $2 \%$, respectively. This error is considered negligible compared with the values of the variability of natural sand porosity that have been presented in the literature $( \pm 46.4 \%)$.

Considering the standard assumption that the porosity of (noncohesive) beach sand is around $40 \%$, absolute sand porosity varied between 25.6 and $43.4 \%$ for the three beaches in this study. At Victoria and Camposoto beaches, the porosity variability was $10 \%$ over the course of the study period, whereas at Atunara was $15 \%$ with maximum relative and cumulative differences in the order of $\pm 40 \%$ over several terms (Fig. 5D).

An important increase in the porosity values was detected immediately after sand dumping at the three beaches. Afterwards, the marine influence (primarily tides and swell waves) produced a gradual decrease in the porosities over several terms until they reached the values of the original beach sand eight months after the nourishment activities. Therefore, the constant effect of swell waves and tides seem to be a key determinant of porosity variability. Most changes were found at zones affected by the tidal range. Thus, the tidal range can be an important clue for controlling the natural depositional porosity of unconsolidated sands. Nevertheless, there is no clear relation between storm waves and porosity changes, and this relationship should be studied in future researches. 

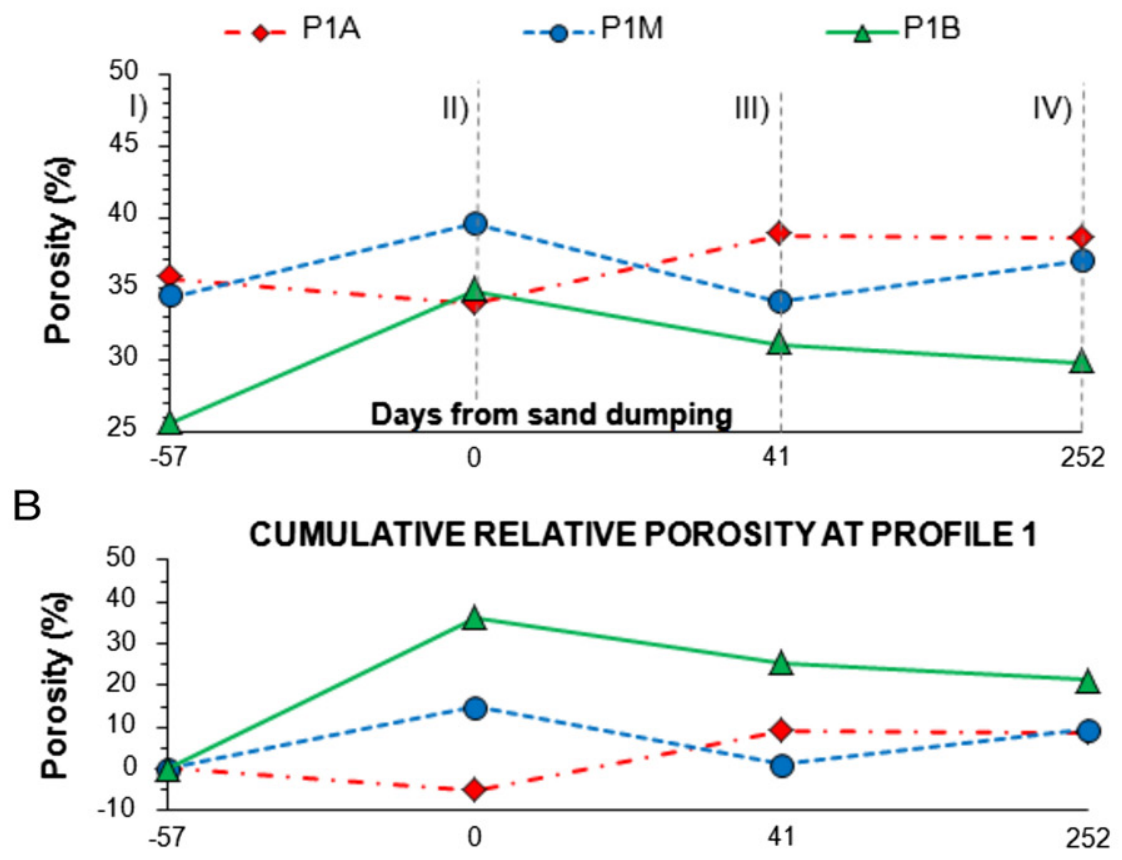

C

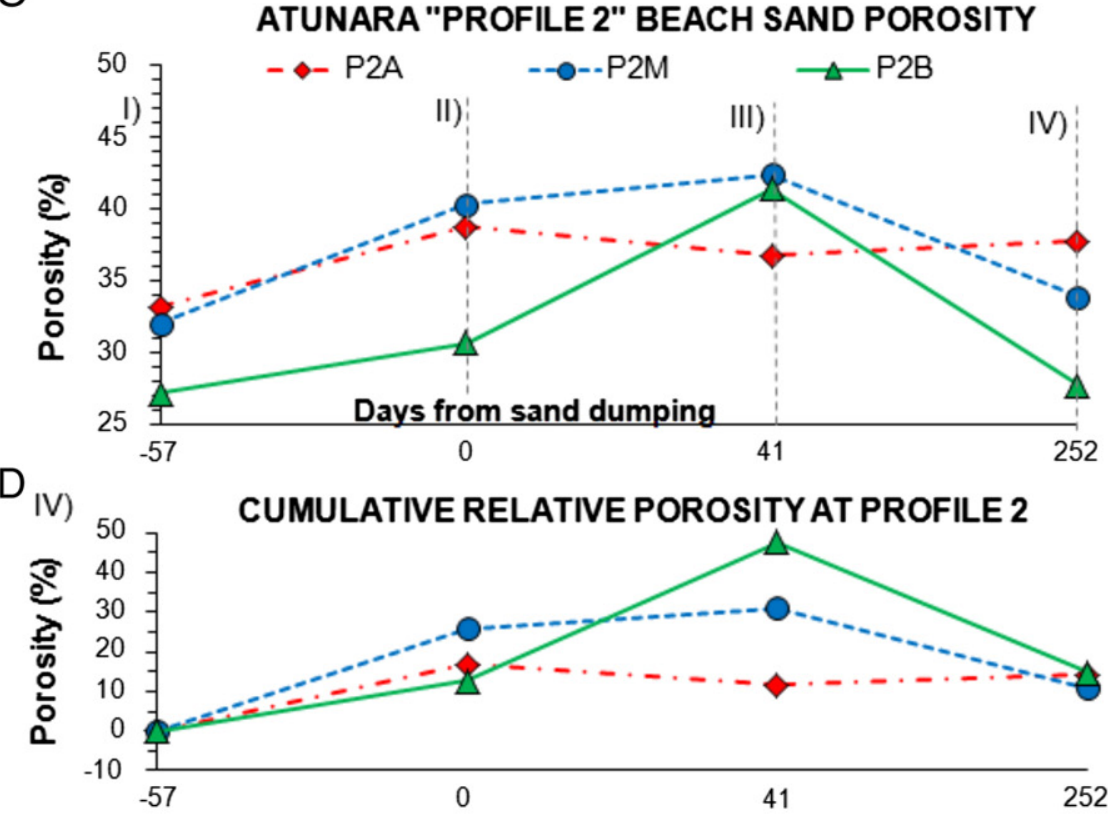

E

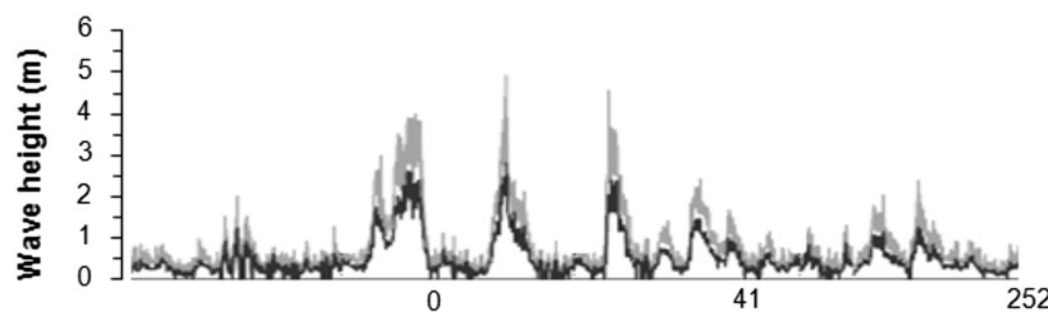

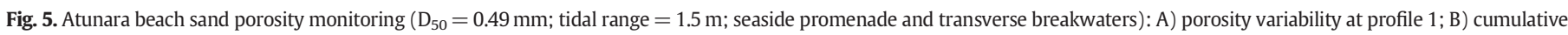

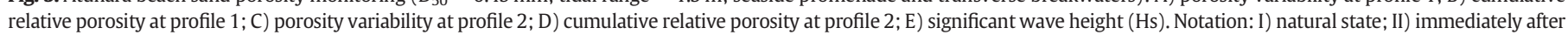
profile nourishment; III) after storm $\mathrm{Hs}=4 \mathrm{~m}$; IV) after storm $\mathrm{Hs}<3 \mathrm{~m}$.

The porosity values obtained from this methodology are consistent and compare well with other data reported from several sources. The consulted literature supports the high porosity variability exhibited by the beaches studied.

\section{Conclusions}

This research has demonstrated that it is possible to measure the insitu bulk density on sandy beaches using a nuclear densimeter gauge 
VICTORIA BEACH PROFILE 1

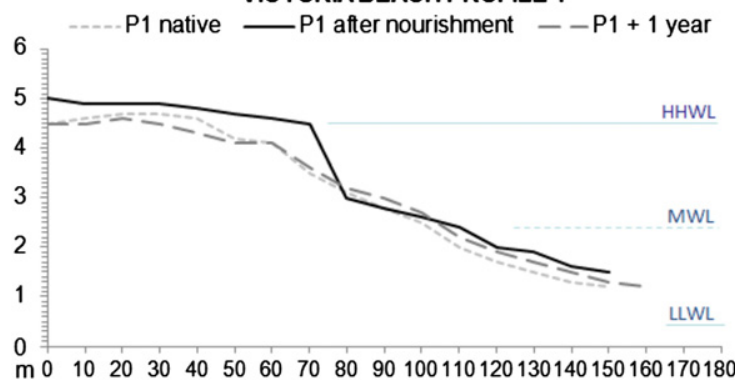

CAMPOSOTO BEACH PROFILE 1

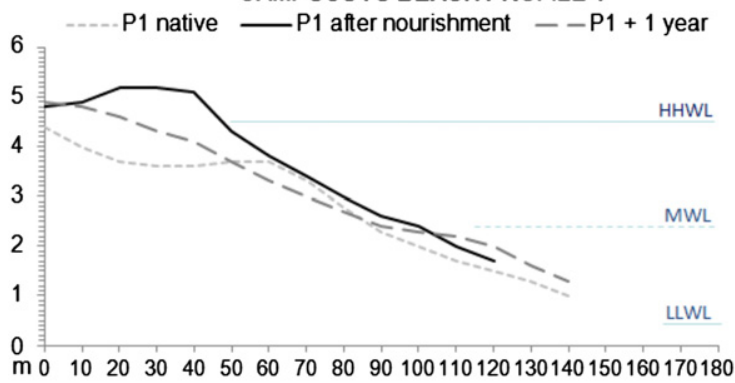

ATUNARA BEACH PROFILE 1

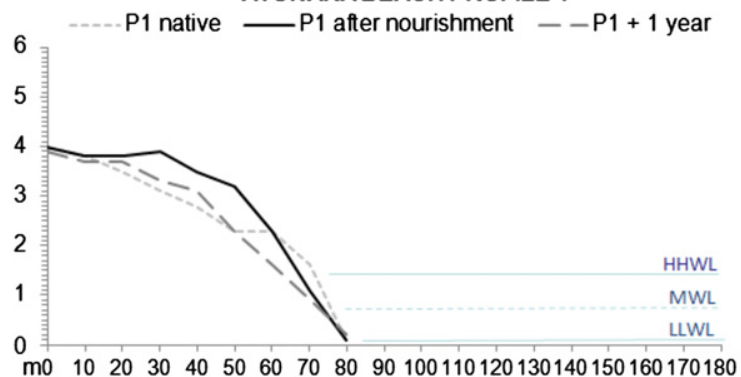

VICTORIA BEACH PROFILE 2

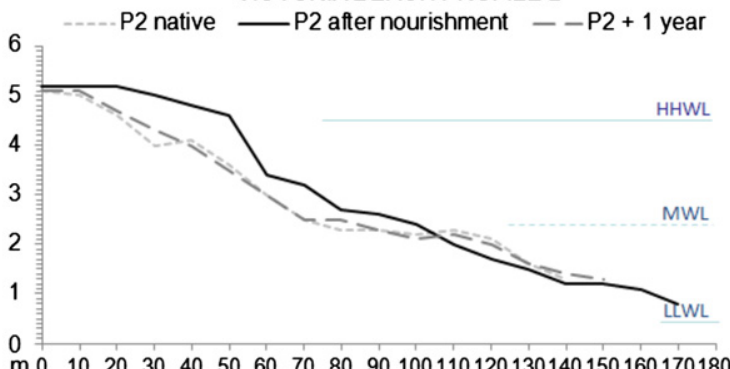

CAMPOSOTO BEACH PROFILE 2

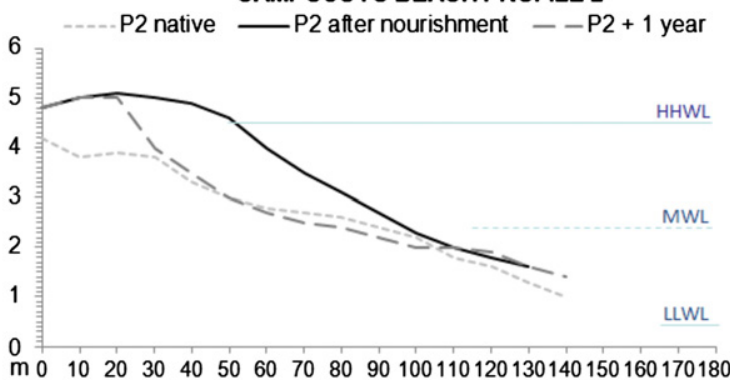

ATUNARA BEACH PROFILE 2

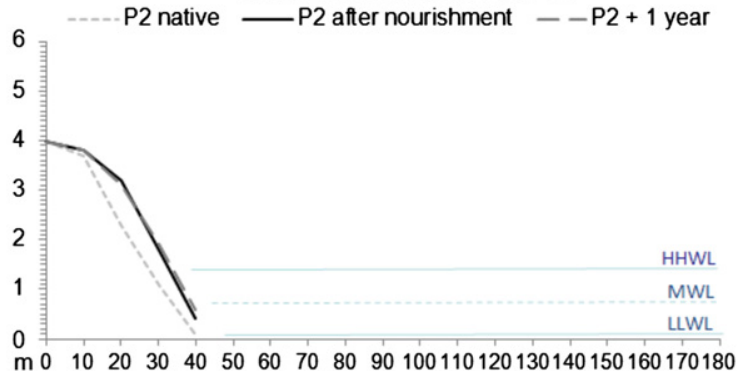

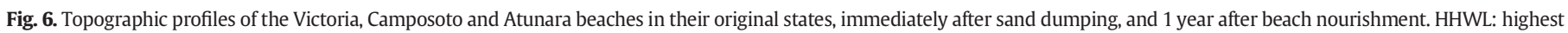
high-water level; MWL: medium water level; LLWL: lowest low-water level.

and, therefore, to accurately compute the porosity. From a technical and economical point of view, this method is rapid, cheap and non-destructive. The modified Proctor test enabled the maximum density of several sands to be determined, with different degrees of compression recorded at the same incident energy level. This ability could represent an important factor in understanding porosity variability. Both techniques can be considered coastal engineering support tools with which to better understand changes in sand volume.

The methodology proposed in this paper exhibits maximum relative errors in the density and porosity measurements of 1.3 and $2.2 \%$, respectively.

The variation in porosity of beach sand in the present study was found to range from 25.6 to $43.4 \%$ for the three analysed beaches, with maximum relative and cumulative differences in the order of $\pm 40 \%$ after beach nourishment for different terms and localities. These findings suggest that the previous assumption of $40 \%$ porosity for natural (non-cohesive) sand beds should be considered only a crude guideline.

In general terms, a very significant increase in the porosity was observed after massive sand dumping, with maximum relative differences of $+11.6 \%$, $+32.5 \%$ and $+36.2 \%$ in Victoria, Camposoto and Atunara beaches, respectively.

The effect of the first tidal cycle (12-24 h) had a minimal effect on the nourished sand porosity at the tidal areas of Victoria and Camposoto beaches. Nevertheless, the cumulative effect of daily tides and equinoctial tides exhibited relative porosity forfeitures of as much as $-18.9 \%$.
For the three studied beaches, sand porosities tended to decrease with time, returning to native values approximately eight months after sand dumping. Moderate storms generally had no significant effect on porosity variability, although no clear relationship was observed between storm waves and porosity changes. Future research should examine the influence of storm waves and season on sand porosity and associated volume changes, as well as the effects of specific grain density, grain shape, grain size, sorting, skewness, kurtosis and water content.

\section{Acknowledgements}

The authors would like to thank the reviewers, whose constructive comments helped to enhance this paper, as well as all the members of the Coastal Engineering research group (RNM-912) for their contribution towards the completion of this project.

\section{References}

Anfuso, G., 2005. Sediment-activation depth values for gentle and steep beaches. Mar. Geol. 220, 101-112.

Arulanandan, K., 1991. Dielectric method for prediction of porosity of saturated soil. J. Geotech. Eng. 117, 319-330.

ASTM Standard D1557, 2012. Standard Test Methods for Laboratory Compaction Characteristics of Soil Using Modified Effort $(56,000 \mathrm{ft}-\mathrm{lbf} / \mathrm{ft} 3(2,700 \mathrm{kN}-\mathrm{m} / \mathrm{m} 3))$. ASTM International, West Conshohocken, PA. http://dx.doi.org/10.1520/D1557-12.

ASTM Standard D6938, 2010. Standard Test Method for In-Place Density and Water Content of Soil and Soil-Aggregate by Nuclear Methods (Shallow Depth). ASTM International, West Conshohocken, PA. http://dx.doi.org/10.1520/D6938-10.

Atkins, J.E., McBride, E.F., 1992. Porosity and packing of Holocene river, dune, and beach sands. Am. Assoc. Pet. Geol. Bull. 76, 339-355. 
Beard, D.C., Weyl, P.K., 1973. Influence of texture on porosity and permeability of unconsolidated sand. Am. Assoc. Pet. Geol. Bull. 57, 349-369.

Bennett, R.H., 1999. Panama City coastal sands DRI sites 10 and GS-172 sediment analyses. SEAPROBE, Inc (Technical Report No. SI-0099-03).

Bennett, R.H., Thwaites, F., Hulbert, M.H., Hulbert, M.E., 1999. Final report part I. NATO phase II field exercise in the C-1 area off the coast of Holland. SEAPROBE, Inc (Technical Report No. SI-0099-01).

Bloom, M., Russell, M.J., Kustau, A., Mandayam, S., Sukumaran, B., 2010. Measurement of porosity in granular particle distributions using adaptive thresholding. IEEE Trans. Instrum. Meas. 59, 1192-1199.

Breslau, L.R., 1967. The normally-incident reflectivity of the sea floor at $12 \mathrm{KC}$ and its correlation with physical and geological properties of naturally-occurring sediments. Technical Report Reference No. 67-16.Woods Hole Oceanographic Institution, Woods Hole, Massachusetts.

Briggs, K.B., 1994. High-frequency acoustic scattering from sediment interface roughness and volume inhomogeneities. Dissertation, University of Miami, Coral Gables, Florida.

Briggs, K.B., Reed, A.H., Jackson, D.R., Tang, D., 2010. Fine-scale volume heterogeneity in a mixed sand/mud sediment off Fort Walton Beach FL. IEEE J. Ocean. Eng. 35, 471-487.

Chuhan, F.A., Kjeldstad, A., Bjørlykke, K., Høeg, K., 2002. Porosity loss in sand by grain crushing - Experimental evidence and relevance to reservoir quality. Mar. Pet. Geol. 19, 39-53.

Curry, C.W., Bennett, R.H., Hulbert, M.H., Curry, K.J., Faas, R.W., 2004. Comparative study of sand porosity and a technique for determing porosity of undisturbed marine sediment. Mar. Georesour. Geotechnol. 22, 231-252.

Davies, J.L., 1964. A morphogenic approach to world shorelines. Z. Geomorphol. Mortensen Sonderh 8, 127-142.

Dean, R.G., 2003. Beach nourishment: theory and practice. Advanced Series on Ocean Engineering. World Scientific Publishing Company, River Edge, New Jersey (399 pp.)

Dickinson, W.W., Ward, J.D., 1994. Low depositional porosity in eolian sands and sandstones, Namib Desert. J. Sediment. Res. A Sediment. Petrol. Process. 64 (A), 226-232.

Ellis, A.J., Lee, C.H., 1919. Geology and Groundwater of the Western part of San Diego County California. U. S. Geol. Surv. Water Supply Pap. 446, 3-131.

Erchul, R.A., 1974. OCEAN ENGINEERING APPLICATIONS FOR ELECTRICAL RESISTIVITY TECHNIQUES. 733-746.

Erchul, R.A., Nacci, V.A., 1972. Electrical Resistivity Measuring System for Porosity Determination of Marine Sediments. Mar. Technol. Soc. J. 6, 47-53.

Evans, R.L., 2001. Measuring the shallow porosity structure of sediments on the continental shelf: A comparison of an electromagnetic approach with cores and acoustic backscatter. J. Geophys. Res. C: Oceans 106, 27047-27060.

Faas, R.W., 2001. Report on research concerning sediment porosity. University of Southern Mississippi, Stennis Space Center, MS. 39529.

Ferreira, O., Ciavola, P., Taborda, R., Bairros, M., Dias, J.A., 2000. Sediment mixing depth determination for steep gentle foreshores. J. Coast. Res. 16, 830-839.

Fraser, H.J., 1935. Experimental study of the porosity and permeability of clastic sediments. J. Geol. 43, 910-1010.

Gaither, A., 1953. A study of porosity and grain relationships in experimental sands. J. Sed. Res. (SEPM) 23, 180-195.

Galvin, C.J., 1979. Relation between immersed weight and volume rates of longshore transport. U.S.Army Coastal Engineering Research Center (Technical Paper).

Godin, G., 1972. The Analysis of Tides. University of Toronto Press, Toronto Ontario (264 pp.).

Gomez-Pina, G., Fages, L., Ramírez, J.L., Muñoz-Pérez, J.J., Enríquez, J., 2007. A critical review of beach restoration projects in the northern coast of Cadiz (Spain) after thirteen years. Proc. Coast. Eng. Conf. 4167-4178.

Graton, L.C., Fraser, H.J., 1935. Systematic packing of spheres-with particular relation to porosity and permeability. J. Geol. 43, 785-909.

Hamilton, E.L., Bachman, R.T., 1982. Sound velocity and related properties of marine sediments. J. Acous. Soc. Am. 72, 1891-1904.

Hamilton, E.L., Menard, H.W., 1956. Density and porosity of sea-floor surface sediments off San Diego California. Am. Assoc. Pet. Geol. Bull. 40, 754-761.

Hamm, L., Capobianco, M., Dette, H.H., Lechuga, A., Spanhoff, R., Stive, M.J.F., 2002. A summary of European experience with shore nourishment. Coast. Eng. 47, 237-264.

Hanson, H., Brampton, A., Capobianco, M., Dette, H.H., Hamm, L., Laustrup, C., Lechuga, A., Spanhoff, R., 2002. Beach nourishment projects, practices, and objectives - A European overview. Coast. Eng. 47, 81-111.

Jackson, P.D., 1975. Electrical resistivity method for evaluating the in-situ porosity of clean marine sands. Mar. Geotechnol. 1, 91-115.

Jackson, P.D., Smith, D.T., Stanford, P.N., 1978. Resistivity-porosity-particle shape relationships for marine sands. Geophysics 43, 1250-1268

Kakinoki, T., Tsujjimoto, G., Yamada, F., Sakai, D., Uno, K., 2011. Beach profile and sediment characteristics of a mixed sand beach under diurnal sea level variations. J. Coast. Res. 765-770.

Kamphuis, J.W., Davies, M.H., Nairn, R.B., Sayao, O.J., 1986. Calculation of littoral sand transport rate. Coast. Eng. 10, 1-21.

King, F.H., 1899. The principles and conditions of the movements of ground water. 19th Annual Report of the USGS (1897-1898).
Kolbuszewski, J.J., 1948. An experimental study of the maximum and minimum porosities of sands. Proceedings of the 2nd International Conference on Soil Mechanics and Foundation Engineering, Rotterdam 1, pp. 158-165.

Ludwick, J.C., 1956. A volumeter for measuring porosity of incoherent sands. J. Sediment Petrol. 26, 276-283.

Lundegard, P.D., 1992. Sandstone porosity loss - a "big picture' view of the importance of compaction. J. Sediment. Petrol. 62, 250-260.

Masselink, G., Short, A.D., 1993. The effect of tide range on beach morphodynamics and morphology: a conceptual beach model. J. Coast. Res. 9, 785-800.

McLachlan, A., Turner, I., 1994. The interstitial environment of sandy beaches. Mar. Ecol. $15,177-211$.

Medina, R., Losada, M.A., Losada, I.J., Vidal, C., 1994. Temporal and spatial relationship between sediment grain size and beach profile. Mar. Geol. 118, 195-206.

Meinzer, O.E., 1923. The occurrence of ground water in the United States. U. S. Geol. Surv. Water Supply Pap. 489, 11-17.

Muñoz-Pérez, J.J., Medina, R., 2000. Profile changes due to a fortnightly tidal cycle. Coastal Engineering 2000 - Proceedings of the 27th International Conference on Coastal Engineering, ICCE 2000 276, pp. X3062-X3075.

Muñoz-Perez, J.J., Medina, R., 2010. Comparison of long-, medium- and short-term variations of beach profiles with and without submerged geological control. Coast. Eng. 57, 241-251.

Muñoz-Perez, J.J., Lopez De San Roman-Blanco, B., Gutierrez-Mas, J.M., Moreno, L., Cuena, G.J., 2001. Cost of beach maintenance in the Gulf of Cadiz (SW Spain). Coast. Eng. 42, 143-153.

Muñoz-Pérez, J.J., Medina, R., Tejedor, B., 2001. Evolution of longshore beach contour lines determined by the E.O.F. method. Sci. Mar. 65, 393-402.

Muñoz-Perez, J.J., Payo, A., Roman-Sierra, J., Navarro, M., Moreno, L., 2012. Optimization of beach profile spacing: An applicable tool for coastal monitoring. Sci. Mar. 76 791-798.

Navarro, M., Muñoz-Pérez, J.J., Román-Sierra, J., Tsoar, H., Rodríguez, I., Gómez-Pina, G., 2011. Assessment of highly active dune mobility in the medium, short and very short term. Geomorphology 129, 14-28.

Packwood, A.R., 1983. The influence of beach porosity on wave uprush and backwash. Coast. Eng. 7, 29-40.

Poizot, E., Anfuso, G., Méar, Y., Bellido, C., 2013. Confirmation of beach accretion by grainsize trend analysis: Camposoto beach, Cádiz, SW Spain. Geo-Mar. Lett. 1-10.

Pryor, W.A., 1972. Reservoir Inhomogeneities of some Recent Sand Bodies. Soc. Petrol. Eng. J. 12, 229-245.

Pryor, W.A., 1973. Permeability-Porosity Patterns and Variations in some Holocene Sand Bodies. Am. Assoc. Pet. Geol. Bull. 57, 162-189.

Reed, A.H., Thompson, K.E., Briggs, K.B., Willson, C.S., 2010. Physical pore properties and grain interactions of SAX04 sands. IEEE J. Ocean. Eng. 35, 488-501.

Reis, A.H., Gama, C., 2010. Use of sand beds of variable permeability in beach profile engineering. AIP Conference Proceedings. 1254, pp. 231-235.

Richardson, M.D., Briggs, K.B., Bibee, L.D., Jumars, P.A., Sawyer, W.B., Albert, D.B., Bennett, R.H., Berger, T.K., Buckingham, M.J., Chotiros, N.P., Dahl, P.H., Dewitt, N.T., Fleischer, P., Flood, R., Greenlaw, C.F., Holliday, D.V., Hulbert, M.H., Hutnak, M.P., Jackson, P.D., Jaffe, J.S., Johnson, H.P., Lavoie, D.L., Lyons, A.P., Martens, C.S., McGehee, D.E., Moore, K.D. Orsi, T.H., Piper, J.N., Ray, R.I., Reed, A.H., Self, R.F.L., Schmidt, J.L., Schock, S.G., Simonet, F., Stoll, R.D., Tang, D., Thistle, D.E., Thorsos, E.I., Walter, D.J., Wheatcroft, R.A., 2001. Overview of SAX99: Environmental considerations. IEEE J. Ocean. Eng. 26, 26-53.

Roberts, J., Jepsen, R., Gotthard, D., Lick, W., 1998. Effects of particle size and bulk density on erosion of quartz particles. J. Hydraul. Eng. 124, 1261-1267.

Román-Sierra, J., Navarro, M., Muñoz-Perez, J.J., Gomez-Pina, G., 2011. Turbidity and Other Effects Resulting from Trafalgar Sandbank Dredging and Palmar Beach Nourishment J. Waterw. Port Coastal Ocean Eng. 137, 332-343.

Román-Sierra, J., Muñoz-perez, J.J., Navarro-Pons, M., 2013. Influence of sieving time on the efficiency and accuracy of grain-size analysis of beach and dune sands. Sedimentology 60, 1484-1497.

Soulsby, R.L., 1991. Dynamics of marine sands. Thomas Telford Publ, London (249 pp.).

Spanish Port System, 2012. Oceanography and meteorology data base. Spanish government (www.puertos.es).

Tang, D., Briggs, K., Williams, K., Jackson, D., Thorsos, E., Percival, D., 2002. Fine-scale volume heterogeneity measurements in sand. IEEE J. Ocean. Eng. 27, 546-560.

Terzaghi, C., 1925. Principles of soil mechanics: V-Physical differences between sand and clay. Engineering News - Record 95. 912-916.

Tickell, F.G., Hiatt, W.N., 1938. Effect of angularity of grain on porosity and permeability of unconsolidated sands. Am. Assoc. Pet. Geol. Bull. 22, 1272-1279.

Trask, P.D., 1931. Compaction of sediments. Am. Assoc. Pet. Geol. Bull. 15, 271-276.

Trembanis, A.C., Pilkey, O.H., 1999. Comparison of beach nourishment along the U.S. Atlantic, Great Lakes, Gulf of Mexico New England shorelines. Coast. Manage. 27, 329-340.

USACE, 2002. Coastal Engineering Manual. Engineer Manual 1110-2-1100. Part III, Chapter I: Coastal sediment properties.U.S. Army Corps of Engineers, Washington, D.C.

Van Rijn, L.C., 2007. Unified view of sediment transport by currents and waves. I: Initiation of motion, bed roughness, and bed-load transport. J. Hydraul. Eng. 133, 649-667.

Wheatcroft, R.A., 2002. In situ measurements of near-surface porosity in shallow-water marine sands. IEEE J. Ocean. Eng. 27, 561-570. 